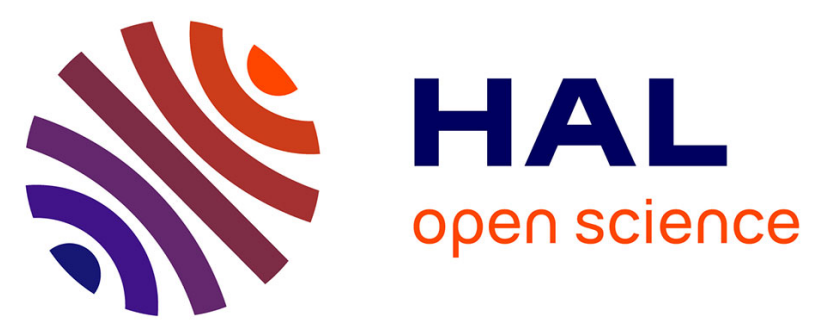

\title{
The mafic-silicic layered intrusions of Saint-Jean-du-Doigt (France) and North-Guernsey (Channel Islands), Armorican Massif: Gabbro-diorite layering and mafic cumulate-pegmatoid association
} Martial Caroff, Nolwenn Coint, Erwan Hallot, Cédric Hamelin, Jean-Jacque Peucat, Gilles Charreteur

\section{To cite this version:}

Martial Caroff, Nolwenn Coint, Erwan Hallot, Cédric Hamelin, Jean-Jacque Peucat, et al.. The mafic-silicic layered intrusions of Saint-Jean-du-Doigt (France) and North-Guernsey (Channel Islands), Armorican Massif: Gabbro-diorite layering and mafic cumulate-pegmatoid association. Lithos, 2011, 125, pp.675-692. 10.1016/j.lithos.2011.03.019 . insu-00589245

\section{HAL Id: insu-00589245 \\ https://hal-insu.archives-ouvertes.fr/insu-00589245}

Submitted on 28 Apr 2011

HAL is a multi-disciplinary open access archive for the deposit and dissemination of scientific research documents, whether they are published or not. The documents may come from teaching and research institutions in France or abroad, or from public or private research centers.
L'archive ouverte pluridisciplinaire HAL, est destinée au dépôt et à la diffusion de documents scientifiques de niveau recherche, publiés ou non, émanant des établissements d'enseignement et de recherche français ou étrangers, des laboratoires publics ou privés. 
1 The mafic-silicic layered intrusions of Saint-Jean-du-Doigt

2 (France) and North-Guernsey (Channel Islands), Armorican

3 Massif: gabbro-diorite layering and mafic cumulate-pegmatoid

6 Martial Caroff ${ }^{a, *}$, Nolwenn Coint $^{a, 1}$, Erwan Hallot ${ }^{b}$, Cédric Hamelin ${ }^{a, 2}$, Jean-Jacques Peucat

${ }^{\mathrm{b}}$, Gilles Charreteur ${ }^{\mathrm{b}}$

8

9 a UMR CNRS 6538 «Domaines Océaniques », IUEM, Université de Brest, 6 avenue Victor Le Gorgeu, CS 93837, 29238 Brest cedex 3, France

$11{ }^{b}$ Géosciences Rennes, UMR CNRS 6118, Université de Rennes 1, 35042 Rennes cedex, 12 France

13

$14 *$ Corresponding author: caroff@univ-brest.fr

15

$16{ }^{1}$ Present address : Department of Geosciences, Texas Tech University, Lubbock, TX 79409 ,

17 USA (nolwenn.coint@ttu.edu)

$18{ }^{2}$ Present address : IPGP, Laboratoire de Géosciences Marines, 4, Place Jussieu 75252 Paris

19 cedex 05, France 
23 Complexes (hereafter referred to as SJIC and NGIC, respectively) are examples of mafic-

24 silicic layered intrusions in the Armorican Massif. Both are characterized by the occurrence of

25 (1) a basal/peripheral gabbroic unit interlayered with sheets (generally dioritic in composition,

26 occasionally gabbroic) and crossed by leucocratic diapirs and pipes (from monzodioritic to Q-

27. monzonitic in composition), (2) peripheral pegmatoids associated with mafic cumulates and

28 (3) coeval granitoids. Beside these main similarities, some contrasted features lead us to

29 propose two distinct models of formation. The Variscan SJIC includes tholeiitic mafic rocks

30 (monzogabbro) that locally mingle and mix with leucocratic components (monzonite or Q-

31 monzonite). The Cadomian NGIC is calc-alkaline. The SJIC sheet-bearing gabbro is

32 homogeneous from a petrologic point of view, whereas the NGIC exhibits gabbroic

33 macrorhythmic sequences with mineral layering. The Sr-Nd isotopic compositions of the SJIC

34 gabbros are significantly different from those of the associated dioritic layers. This is not the

35 case in the NGIC where the magmas could be cogenetic. We argue that the SJIC gabbro was a

36 liquid that crystallized in situ without significant crystal settling. By contrast, the rhythmic

37 sequences of the NGIC are consistent with crystal accumulation. Subsequently, both can be

38 seen as mafic reservoirs which were repeatedly invaded by magmas of intermediate

39 composition. We interpret the sheets in the SJIC as the result of horizontal spreading of

40 dioritic metastable magmas into a gabbroic reservoir crystallizing from below, at levels of

41 neutral buoyancy. Injections and convection in the central part of the reservoir possibly

42 resulted in spectacular mixing/mingling structures. In the NGIC, the emplacement of the

43 dioritic sheets was rather controlled by pre-existing rhythmic cumulative structures. In both

44 intrusions, late differentiated diapirs were extracted from the dioritic sheets. Associated 
45 peripheral pegmatoids are thought to result from the crystallization of liquids issued from a

46 mafic intercumulus melt in the presence of a fluid phase. This extraction might have been

47 enhanced by the disruption of the peripheral cumulate stack, perhaps following pressure

48 drops.

50 Keywords: Gabbro; Diorite; Granite; Layered intrusion; Replenishment; Armorican Massif

\section{Introduction}

The term MASLI (MAfic-Silicic Layered Intrusion), as first proposed by Wiebe

55 (1993a and b), refers to plutonic complexes with interlayered mafic (gabbroic) and

56 intermediate/felsic (dioritic to granitic) rocks (Wiebe, 1996; Franceschelli et al., 2005).

57 MASLIs can be recognized by distinctive field relationships which always include (i) lobate

58 contacts between the main gabbro-dioritic intrusions and surrounding or underlying

59 granitic/granodioritic plutons and (ii) layers, sheets, diapirs, and/or veins of dioritic/silicic

60 material into gabbroic units (Wiebe, 1996). Other features commonly (but not always)

61 described in such complexes are: (iii) macrorhythmic gabbro-dioritic units, from less than one

62 to several tens of meters thick, with chilled bases (Wiebe, 1993b, 1994, 1996; Waight et al.,

63 2007), (iv) modal layering and feldspar lamination in the dioritic/silicic layers (Wiebe, 1996),

64 (v) mafic/intermediate enclaves in the granites (Wiebe, 1994; Wiebe et al., 1997), and (vi)

65 basaltic pillow-like chilled bodies within felsic units (Wiebe, 1974, 1993b; Wiebe et al,

66 2001). Although differences exist between the examples, Wiebe and others first proposed a

67 comprehensive model to account for these features: repeated mafic injections into a felsic

68 chamber, from dioritic to granitic composition, followed by fractional crystallization and

69 complex liquid-liquid (and/or partially crystallized magma-magma) interactions including 
small scale diapirism and hybridization. More recently, MASLIs were recognized to result

71 from multiple replenishments of mafic and felsic magmas, mingling and limited mixing, and

72 rejuvenation of granite (Wiebe et al., 2007).

If the Cadomian layered gabbro-diorite complex of North-Guernsey (Channel Islands)

74 was suspected by Wiebe (1996) to be a MASLI, the Variscan intrusion of Saint-Jean-du-Doigt

75 (France) was never considered as such. However, both Armorican plutonic bodies display

76 many of the features characteristic of mafic-silicic layered intrusions. Additionally, both

77 complexes show spectacular pegmatoid (gabbroic pegmatite) occurrences systematically

78 associated with coarse-grained mafic cumulates. Such a lithologic association has already

79 been described in various gabbroic intrusions (Smartville intrusive complex, California:

80 Beard and Day, 1986; Kraemer macrodyke, Greenland: Momme and Wilson, 2002; Mount

81 Sheridan gabbro, Oklahoma: McEllen, 2006), but not specifically in MASLIs. In spite of their

82 similarities, each Armorican intrusion shows distinctive petrological and geochemical

83 (isotopic) characters.

The aim of this study is to reexamine the published models of MASLI formation

85 through these two new examples from the Armorican Massif, which display both shared and

86 contrasted features. This leads us to propose distinct processes of construction emphasizing

87 the possibility that replenishment of mafic chambers by intermediate partially crystallized

88 magmas explains some features of MASLIs.

90 2. Analytical techniques

91

92 Compositions of mineral phases were obtained with a Cameca SX50 automated

93 electron microprobe (Microsonde Ouest, Brest). Analytical conditions were $15 \mathrm{kV}, 15 \mathrm{nA}$, 
94 counting time $6 \mathrm{~s}$, correction by the ZAF method. Concentrations $<0.3 \%$ are considered 95 qualitative.

Major and trace element compositions (Table 1) were measured at the University of

97 Brest on whole rock powders by inductively coupled plasma atomic emission spectrometry 98 (ICP-AES). Analytical methods are described in Cotten et al. (1995). Relative standard

99 deviations are $<2 \%$ for major elements and $<5 \%$ for trace elements. For the coarsest-grained 100 samples, a large quantity of rock was crushed in a steel jaw-crusher (e.g., $20 \mathrm{~kg}$ for the 101 pegmatoid SJ16). After the crushed rock was quartered, a representative split was pulverized 102 in an agate mill.

103 The Sr-Nd isotopic compositions were obtained from whole rock powders with a

104 Cameca TSN 206 mass spectrometer (Guernsey) and with a Finnigan MAT 262 mass

105 spectrometer (Saint-Jean-du Doigt) at Géosciences Rennes. Sr, Rb, Sm and Nd contents were 106 measured by isotope dilution except for the SJIC samples in which Rb was determined by 107 ICP-AES. Errors on ${ }^{87} \mathrm{Rb} /{ }^{86} \mathrm{Sr}$ and ${ }^{147} \mathrm{Sm} /{ }^{144} \mathrm{Nd}$ ratios are $2 \%$ and $1 \%$, respectively. Details of 108 analytical procedures are described in Peucat et al. (1999). ${ }^{87} \mathrm{Sr} /{ }^{86} \mathrm{Sr}$ ratios were normalized to 109 the NBS 987 standard $\left({ }^{87} \mathrm{Sr} /{ }^{86} \mathrm{Sr}=0.71025\right)$ and ${ }^{143} \mathrm{Nd} /{ }^{144} \mathrm{Nd}$ ratios to the AMES standard $110\left({ }^{143} \mathrm{Nd} /{ }^{144} \mathrm{Nd}=0.511963\right) . \varepsilon_{\mathrm{Nd}}$ values, in Table 2, were calculated using ${ }^{143} \mathrm{Nd} /{ }^{144} \mathrm{Nd} \mathrm{CHUR}=$ 1110.51264 and ${ }^{147} \mathrm{Sm} /{ }^{144} \mathrm{Nd}_{\mathrm{CHUR}}=0.1967$. They correspond to: $\varepsilon_{(0)}=10^{4}\left(\left(^{143} \mathrm{Nd} /{ }^{144} \mathrm{Nd}_{\text {sample }} /\right.\right.$ $112051264)-1)$ and $\varepsilon_{(\mathfrak{t})}=\varepsilon_{(0)}-\left(25.1\left(\left({ }^{147} \mathrm{Sm} /{ }^{144} \mathrm{Nd}\right.\right.\right.$ sample -1$\left.\left.) / 0.1967\right) \Delta_{(\mathrm{t})}\right)$, following De Paolo 113 (1988).

\section{3. Saint-Jean-du-Doigt Intrusive Complex (SJIC)}


120 domain, mainly composed of volcanoclastic formations overlying a Palaeoproterozoic

121 (Icartian) gneissic basement (c. 2.0 Ga, Auvray et al., 1980), and the Léon Hercynian

122 metamorphic domain (Fig. 1a). The SJIC is composite and includes four main units: the

123 Primel cumulate-pegmatoid association, the Saint-Jean-du-Doigt monzogabbro-(Q-

124 )monzonite mingled/mixed rocks, the Poul Rodou layered gabbro-diorites and several granitic

125 bodies (Fig. 1b). Some doleritic dykes cross cut the units, but were not found in the granitic

126 rocks. Most rocks have isotropic textures and exhibit no significant regional deformation

127 subsequent to their emplacement, with the exception of local brittle faulting. However, they

128 have undergone late- to post-magmatic alterations, resulting in the transformation of some

129 primary minerals, without significant change in bulk rock chemistry (Coint et al., 2008). The

130 SJIC was emplaced under a lithostatic pressure of about $0.5 \mathrm{GPa}$, i.e. at $c .15 \mathrm{~km}$ depth

131 (amphibole geobarometry: Johnson and Rutherford, 1989 and Schmidt, 1992 in Coint et al.,

132 2008), within Proterozoic rocks and Devonian-Carboniferous sediments. Chantraine et al.

133 (1986) have reported a carboniferous U-Pb zircon age of $c .350 \mathrm{Ma}$ for the gabbros (Deutsch,

134 unpublished) confirmed by Barboni et al. (2008, 2010), who obtained U-Pb zircon ages at 347

$135 \pm 4$ Ma for the mafic units and the granitic bodies from Poul Rodou. The SJIC was later

136 intruded by red granites at c. $300 \mathrm{Ma}$ (Fig. 1b). The SJIC mafic rocks have a tholeiitic affinity

137 (Chantraine et al., 1986; Coint et al., 2008, 2009; see also section 5.2). Geochemical features

138 of intermediate/felsic rocks are rather typical of calc-alkaline suites (Barboni et al., 2010;

139 Capdevila, 2010). 
144 shoreline. Field observations have been made from Poul Rodou to Primel through the bay of

145 Saint-Jean-du-Doigt (Fig. 1b).

147 3.2.1. Poul Rodou: gabbro-diorite layering

148 From southeast to northwest, the Poul Rodou cross-section begins with a small

149 granitic body in sharp intrusive contact with a Proterozoic formation (Fig. 1b and 2a). The

150 granite is equigranular and intrudes an intergranular/oikocrystic gabbro. Lobate contacts

151 between the granite and the adjacent gabbro and gabbroic enclaves within the granite are

152 interpreted as evidence for the contemporaneous crystallization of both magmas. Other

153 granitic intrusions crop out along the shoreline, such as the Beg ar Fri granite (sample SJ22,

154 Fig 1b and 2a). Several sub-parallel leucocratic sheets form layers within the gabbro. They are 155 oriented SE-NW and dip slightly $\left(10^{\circ}\right.$ to $\left.30^{\circ}\right)$ toward the northeast. They are cut

156 southeastward by the granitic intrusion (Fig. 2a). This demonstrates the lack of apparent direct

157 link between leucocratic sheets and granitic bodies. Leucocratic sheets are thin (a few

158 decimeters thick) and sparse near the edge of the complex. They become thicker (up to

159 several decimeters) and more abundant to the northwest. The spacing from one sheet to

160 another varies from several decameters to a few meters. The upper contact with the overlying

161 gabbro is systematically undulated, sometimes connected to felsic masses, a few decimeters in

162 size, within the overlying gabbro (Fig. 3a, b). When elongated, these structures are orientated

163 sub-perpendicularly to the sheet layers. They are interpreted as gravity-driven felsic diapirs

164 extracted from the sheets. In the present orientation, these instabilities are not sub-vertical and

165 the sheets are not sub-horizontal. The variable dipping angles of the structures along the Poul

166 Rodou shoreline are consistent with post-emplacement brittle deformation and denotes

167 northeastward tilting of blocks limited by NE-SW faults (Fig. 2a). The composition of the 
168 leucocratic sheets is dioritic, with the exception of their upper part, sometimes Q-monzonitic

169 (Table 1). All are moderately cumulative in plagioclase (cumulus from $20 \%$ at the base to

$17050 \%$ at the top of the sheets) and generally exhibit an intergranular texture. Felspar-rich

171 (plagioclase and orthoclase) diapirs, more differentiated than their related sheets, have

172 textures ranging from intergranular to pegmatitic. Contrasting with the upper contacts, bases

173 of the leucocratic sheets form relatively regular surfaces with the underlying gabbro. Some

174 sheets are connected from below to sub-perpendicular pipe-like feeding structures (Fig. 3b

175 and c). In addition, when diapirs came near an overlying sheet, they could merge with it.

176 Alternatively, some diapirs did not intersect the overlying sheet but formed concave-down

177 structures (Fig. 3d). Except near Beg ar Fri, where an amphibole-rich cumulate has been

178 sampled (SJ44b, Fig. 2a), the gabbro is structurally and texturally homogeneous throughout

179 the Poul Rodou shoreline: no chilled margins, macrorhythmic units, or upward petrographic

180 gradation were observed.

182 3.2.2. Saint-Jean's bay: monzogabbro-monzonite interactions

183 The coast north of Saint-Jean-du-Doigt exposes spectacular and various monzogabbro-

184 (Q-)monzonite (see section 3.3 for rock nomenclature) interaction structures resulting from

185 brittle brecciation to mixing (producing hybrid rocks) through mingling (during which the

186 magmatic end-members retain their identity). At Saint-Jean's bay, angular breccias are

187 present only east of the dextral fault $F$ (Fig. 1b) whereas mingling/mixing predominates

188 westward. Lobate structures are also visible in the transition zone to the Poul Rodou layered

189 gabbro-diorite unit.

190 Structures that result from ductile interactions between coexisting magmas include

191 pillowed mafic enclaves with chilled margins enclosed in a heterogeneous monzogabbro

192 (mingling, Fig. 4a), hybrid magmas (pure mixing), and banded rocks in the process of 
193 hybridization (mingling/mixing, Fig. 4b). In partly hybridized rocks, several mafic enclaves

194 show diffuse margins. These interactions can be observed from microscopic (less than one

195 millimeter) to outcrop scales (several tens of meters). Locally, mafic enclaves present a

$196 \mathrm{~N} 40^{\circ} \mathrm{E}$ preferred orientation, suggesting ductile deformation in protoshear zones.

197 The angular facies consist of jigsaw-type breccias where polyhedral mafic enclaves are 198 enclosed in intermediate rocks forming a vein network (Fig. 4c). The veins are texturally

199 homogeneous intergranular (Q-)monzonites whereas a few blocky clasts exhibit

200 mixing/mingling features.

\subsubsection{Primel: cumulate-pegmatoid association}

Pegmatoids (gabbroic pegmatites), generally associated with plagioclase-phyric

204 cumulates, are distributed from Roc'h Louet to Primel (Fig. 1b). Cumulates are well exposed

205 at Roc'h Louet (Fig. 2b), whereas the coarsest-grained pegmatoid, containing large amphibole

206 crystals (up to 15 centimeters in length) and smaller plagioclase crystals, occurs westward

207 near the Primel red granite (Fig. 2c). There, pegmatoids occur as pods or veins within mafic

208 heteradcumulates with variable plagioclase contents. They are sometimes zoned, with an

209 amphibole-richer core. Pegmatoids are often more altered than the host gabbro. The cumulate-

210 pegmatoid association is bordered southward and southeastward by the monzogabbro-(Q-

211 )monzonite unit of Saint-Jean. In this area, monzogabbros are locally rich in feldspar

212 megacrysts, similar to those described by Wiebe and Collins (1998) and Collins et al. (2006)

213 in the Devonian Kameruka Granodiorite (Bega batholith, southeastern Australia). Fine-

214 grained pegmatoids are found as patches or thin veins in mingled monzogabbro-(Q-

215 )monzonite at Saint-Jean's bay western edge (Fig. 2b). In this zone, mottled pegmatoids have

216 also been observed. They are characterized by recrystallized amphibole-bearing flecks from 2

217 to $5 \mathrm{~cm}$ in diameter (see section 3.3 ). 
219 irregular veinlets (Fig. 4d). They are distinct from the doleritic dykes, which display sharp

220 intrusive contacts with host rocks and have chilled margins.

221 In sample PM2 (Fig. 4d), an aplitic vein separates the pegmatoid from the cumulate,

222 the latter being edged by a dark reaction zone.

223

\subsection{Petrology}

According to the recommendations of the IUGS, the nomenclature of plutonic rocks is

227 based on modal compositions. As not all the primary phases are preserved, we have chosen to 228 use the R1-R2 chemical discrimination diagrams of La Roche et al. (1980), as utilized by 229 many authors (e.g., López-Moro and López-Plaza, 2004; Hellström et al., 2004).

231 olivine gabbro; diorite, monzodiorite and (Q-)monzonite (sheets and diapirs); and granite

232 (intrusions). The Saint-Jean's bay samples plot as follow: olivine gabbro (doleritic dykes);

233 monzogabbro, monzonite, and Q-monzonite (mixing/mingling facies). At Primel, pegmatoids

234 are olivine gabbros. Associated cumulates plot as pyroxenite, a term not used here, given the

235 lack of modal pyroxene in the rocks. Following a similar line of argument (lack of olivine),

236 we prefer the term "gabbro" to "olivine gabbro".

237 The Primel cumulates mainly enclose labradorite, secondarily albitized, as a cumulus 238 phase (from 30 to 65 vol. \%), with interstitial actinolite (which replaces oikocrysts, probably 239 of pyroxene), Fe-Ti oxides and apatite.

Pegmatoids are mainly composed of skeletal green hornblende and elongated albitized

241 plagioclase. Relics of diopside have been identified in a few samples. Small comb-shaped Fe242 Ti oxides, biotite and acicular apatite fill the spaces between the large crystals. The flecks of 
243 the mottled pegmatoids on the western edge of Saint-Jean's bay contain Fe-Ti oxides,

244 amphibole and phyllosilicates. They might result from recrystallization of ancient oikocrystic 245 pyroxenes.

246 Gabbros and monzogabbros from the SJIC contain saussuritized plagioclase laths,

247 green hornblende, acicular actinolite, Fe-Ti oxides, apatite, biotite and sparse titanite and

248 zircon. Large oikocrysts of brown hornblende have been identified in several monzogabbro

249 samples. The dolerites are fine-grained and have a typical greenschist facies mineral

250 assemblage (albite, actinolite, epidote, chlorite).

251 The SJIC (Q-)monzonites are especially rich in andesine (up to 75 vol. \%). The main

252 ferro-magnesian mineral is actinolite. The Q-monzonites, which are mainly located east of

253 Saint-Jean's bay, have more than 10 vol. \% of quartz. Sheets and diapirs from the SJIC range

254 from diorite to Q-monzonite in composition. Sheets are rich in albitic plagioclase but also

255 contain amphibole (green hornblende and actinolite) with variable amounts of interstitial

256 quartz. Diapirs contain quartz, plagioclase, K-felspar and epidote.

257 Granites contain orthoclase, quartz, plagioclase, biotite, apatite and rare zircons.

258 Symplectitic quartz-feldspar associations are present in many SJIC granitic samples

259 (myrmekite).

260

261 4. North-Guernsey Intrusive Complex (NGIC)

4.1. Geology

266 Armorican Massif (Fig. 1a). The island is divided into two main geological domains. The

267 Southern Metamorphic Complex mainly consists of Palaeoproterozoic gneisses (including the 
Icart orthogneiss, with a magmatic U-Pb/zircon age of $2061 \pm 2 \mathrm{Ma}$, Samson and D'Lemos,

269 1998), which were later intruded by the deformed Neoproterozoic Perelle Q-diorite (Samson

270 and D'Lemos, 1999). The Northern Neoproterozoic Intrusive Complex - hereafter referred to

271 as the North-Guernsey Intrusive Complex (NGIC) - is undeformed and partly composed of

272 layered rocks (Elwell et al., 1960, 1962; Bremond d'Ars, 1990; Bremond d'Ars et al., 1992).

273 The composite NGIC consists of four distinct units: the Saint Peter Port gabbro, the gabbro-

274 dioritic Bordeaux Group, the L'Ancresse granodiorite and the Cobo granite (Topley et al.,

275 1990; Fig. 1c). All these plutonic units were emplaced at the end of the Cadomian orogeny, at

276 about 560-550 Ma (Bremond d'Ars et al., 1992). The present study mainly deals with gabbro-

277 diorite layering in the Bordeaux Group (the Beaucette type in Bremond d'Ars et al., 1992) and

278 with the Spur Point cumulate-pegmatoid association (Saint Peter Port Gabbro). Alteration of

279 the NGIC rocks is generally moderate. Petrologic studies indicate that the Saint Peter Port

280 gabbro was emplaced under a lithostatic pressure of about $0.4 \mathrm{GPa}(c .12 \mathrm{~km}$ depth),

amphibole and plagioclase crystallized at about $940^{\circ} \mathrm{C}$ under relatively high oxygen fugacity conditions, and magma water content ranged from 2 to $6 \mathrm{wt} \%$ (Bremond d'Ars et al., 1992).

283 The complex has a calc-alkaline affinity (Bremond d'Ars et al., 1992; see also section 5.2)

284 and belongs to the M-type Cadomian Granitoid Belt of Graviou and Auvray (1985).

\subsection{NGIC layering}

\subsubsection{Beaucette Marina: veined gabbroic macrorhythms}

290 partially cumulative macrorhythmic sequences, which are less than one to several meters

291 thick, and dip $20^{\circ}$ westward (Fig. 2 d, e and $5 a, b, c$ ). They are locally intruded by doleritic or 292 dioritic dykes. Each macrorhythm is composed of a gabbroic unit overlying a melagabbroic 
293 unit. The base of a melagabbroic unit is generally fine-grained, as also observed by Elwell et

294 al. (1960). The transition from a melagabbroic unit to an overlying gabbroic one is

295 gradational, with amounts of phyric amphiboles decreasing upwards (see Fig. 9 insets in

296 section 5.1). Both units have an orthocumulate texture. While melagabbroic units are

297 petrologically homogeneous, the main gabbroic unit is formed by alternating dark and

298 mesocratic layers of a few centimeters thick (Fig. 5c) and is veined by leucocratic material,

299 forming an inter- and cross-connected network of centimeter-thick sheets, broadly parallel to

300 the layering (Fig. 5d).

301 Immediately below some melagabbroic units, thick evolved-gabbroic sheets are

302 observed, from which leucocratic pipes protrude upwards into the overlying melagabbros

303 (Fig. 5a, b). Such pipe-producing sheets also occur, more rarely, in the interior of the

304 melagabbroic units (Fig. 5a). They have a texture ranging from intergranular to

305 orthocumulative. The upper limit of the evolved-gabbroic sheets is irregular, sometimes

306 diffuse. Elwell et al. (1960) has described fine-grained margins in the upper part of some

307 gabbroic units at the contact with the pipe-producing sheets. All the leucocratic pipes are

308 inclined on average at about $30^{\circ}$ from the main layering (Fig. 5e). They plunge toward the S-

309 SE. North of the area shown in Fig. 2e, two generations of neighboring pipes have distinct

310 pitches (c. $10^{\circ}$ and $40^{\circ}$ from the layering). Pipe compositions range from monzodiorite (this

311 study) to granodiorite (Elwell et al., 1960). In cross-section, the pipes are zoned, the core

312 being less differentiated than the rim (Fig. 5f; Elwell et al., 1960). The upper part of the pipes

313 is pegmatitic and the host rocks are systematically altered near the pegmatitic zones (Fig. $5 \mathrm{f}$ ).

314 Elwell et al. (1960) have described two spots where pipes join with the overlying cross-

315 connected dioritic vein system.

317 4.2.2. Spur Point: cumulate-pegmatoid association 
The Saint Peter Port gabbro is a $0.8 \mathrm{~km}$-thick layered slab, gently dipping westward

319 (Briden et al., 1982). It is composed of three main rock types (Bremond d'Ars et al., 1992).

320 The most spectacular of which is the mottled orthocumulate of Spur Point, characterized by

321 layers of poikilitic amphibole crystal flecks (Roach, 1971; Bremond d'Ars, 1990; Bremond

322 d'Ars et al, 1992; Fig. 6a, b). This facies has been interpreted as a boundary layer cumulate

323 (Bremond d'Ars et al, 1992).

324 Pegmatoidic rocks crop out at Spur Point (Fig. 6c). Their mineralogy and texture are

325 similar to those in the SJIC. However, here in the NGIC, cumulates associated with

326 pegmatoids are mottled.

327

328 4.3. Petrology

329

In a R1-R2 diagram (La Roche et al., 1980), Beaucette's rocks are gabbronorite

331 (melagabbroic units), olivine gabbro (gabbroic units and pipe-producing sheets), diorite

332 (dykes and cross-connected veins), and monzodiorite (pipes). As for Primel (SJIC), the Spur

333 Point cumulates plot as pyroxenite, a term not used here.

334 The Spur Point mottled orthocumulates contain cumulus calcic plagioclase (An 80)

335 and clinopyroxene (Fig. 6b). The intercumulus phases are clino- and orthopyroxene,

336 amphibole (hastingsite), Fe-Ti oxides and apatite. The flecks correspond to large oikocrystic

337 amphiboles.

338 The NGIC pegmatoids are composed of large skeletal green hornblende, elongate

339 albitized plagioclase, comb-shaped Fe-Ti oxides, biotite and acicular apatite.

340 Gabbroic and granitic rocks have also mineralogies comparable to those of the SJIC

341 gabbros and granites. The melagabbros (gabbronorites) show green hornblende as cumulus 
342 phase (<50 vol. \%), as well as plagioclase, Fe-Ti oxides, apatite and biotite. We have also

343 noted the presence of clots of small amphibole grains in these rocks.

344 In Beaucette, the dioritic veins, sheets and dykes are mainly composed of plagioclase,

345 hornblende and biotite, whereas the monzo/granodioritic pipes are rich in plagioclase, K-

346 felspar, green hornblende and, occasionally, quartz and clinopyroxene. The sheet sample

347 GS13a is composed of c. $30 \%$ of $2 \mathrm{~mm}$-long zoned plagioclase, as cumulus phase.

348 Concentrations of acicular hornblende are observed where pipes connect overlying cross-

349 connected dioritic veins (Elwell et al., 1960).

350 The pipe-producing evolved gabbroic sheet sample GS13a from Beaucette and the

351 mottled orthocumulate sample GS1a from Spur Point are both characterized by cumulus An-

352 rich plagioclase (An 60-90: Fig. 7a). No other analyzed NGIC sample shows such a

353 characteristic. A chemical profile across such a plagioclase crystal (sample GS1a, Fig. 7b)

354 reveals a calcic mantle (An 60-75) comprised between an An-rich core (An 75-90) and an An-

355 poor margin (An 40-55). This mineralogical specificity will be discussed in section 6.3.1.

357 5. Geochemistry

\subsection{Geochemical sections through gabbro-diorite units}

Vertical variations of $\mathrm{MgO}, \mathrm{TiO}_{2}$ and $\mathrm{Al}_{2} \mathrm{O}_{3}$ through four gabbro-dioritic sections are shown in Figs 8 (SJIC) and 9 (NGIC). The chemical composition of the Poul Rodou gabbro is relatively constant, above and below the diapir-producing leucocratic sheets, for all the sections (Fig. 8). Only $\mathrm{TiO}_{2}$ varies significantly, from 1.18 (SJ34g) to $1.91 \mathrm{wt} \%$ (SJ43f). This relative chemical homogeneity of the mafic body is a rather original feature with respect to many other MASLIs (e.g., Wiebe, 1996). By contrast, the macrorhythmic sequences of the 
367 NGIC display variable compositions (Fig. 9). Melagabbros are highly magnesian, with MgO

368 contents up to $14.35 \mathrm{wt} \%$ (GS10d). MgO is slightly higher in the lower part of the

369 melagabbroic units (GS7a versus GS7d in Fig. 9). Gabbroic units are more heterogeneous and

370 less magnesian $(5<\mathrm{MgO}<10 \mathrm{wt} \%$, Fig. 9). The leucocratic veins, sheets and diapirs/pipes

371 display various compositions. In both intrusions, the diapirs/pipes are systematically more

372 evolved than the sheets from which they are extracted (SJ34b1 versus SJ34c; GS10c versus

373 GS13a; Table 1 and Figs 8 and 9). However, parts of some sheets are more differentiated than

374 some diapirs. For example, the upper part of the sheet SJ43c is more evolved than the diapir

375 SJ34b1, which relates to another sheet (Table 1 and Fig. 8).

\subsection{Trace elements}

Trace elements which are both incompatible and immobile can be used to determine

380 the magmatic affinity of the mafic rocks. In the $\mathrm{La} / 10-\mathrm{Y} / 15-\mathrm{Nb} / 8$ diagram (Fig. 10) of

381 Cabanis and Lecolle (1989), the SJIC gabbros and monzogabbros plot mainly in the E-MORB

382 field whereas the gabbros and melagabbros from the NGIC clearly have a calc-alkaline 383 affinity.

The chondrite-normalized rare earth element (REE) field of the Poul Rodou gabbros

385 (SJIC) is shown in Fig. 11a, with REE patterns of two leucocratic sheets and related diapirs.

386 The sheet and diapir SJ34 are moderately differentiated. The diapir SJ34b1 is slightly

387 enriched in light REE (LREE) and depleted in heavy REE (HREE) with respect to the

388 corresponding sheet SJ34c, which plots above the gabbroic field. The sheet sample SJ43c

389 shows lower REE concentrations than the less differentiated sheet sample SJ34c. The diapir

390 SJ43d is enriched in LREE and depleted in HREE with respect to its parental sheet SJ43c.

391 Both have positive Eu anomalies. 
The REE patterns of some other rocks representative of the SJIC are exhibited in Fig.

393 11b. Pattern similarities between the diapir SJ34b1 and the monzonite SJ9 (mingling zone at

394 Saint-Jean's bay) and between the evolved sheet SJ43c and the Q-monzonite SJ17 (vein in

395 breccia with angular clasts at Saint-Jean's bay) are noticeable. The pegmatoid SJ16 is less rich

396 in REE than the gabbros. Of all the samples, cumulates have the lowest REE contents. With

397 respect to the monzonite SJ9, the granite SJ22 is enriched in Ce and HREE, and displays a

398 large negative Eu anomaly.

399 In the NGIC, all the samples from the macrorhythmic sequences have parallel patterns

400 (Fig. 11c). This is also the case for the pipe-producing gabbroic sheet GS13a, located near the

401 upper limit of the gabbroic REE field. By contrast, the thin dioritic sheet GS7c and the

402 monzodioritic pipe GS10c are highly depleted in HREE with respect to GS13a. Although

403 contents of $\mathrm{La}, \mathrm{Eu}$ and $\mathrm{Yb}$ are equal in GS10c and GS7c, GS10c has a concave-up shaped

404 pattern indicating depletion in Middle REE (with the exception of Eu).

The gabbroic pipe-producing sheet GS13a and the mottled cumulate of Spur Point

406 GS1a, which contain An-rich plagioclase phenocrysts (An 60-90: Fig. 7), display cross-

407 cutting REE curves, with comparable Eu contents (Fig. 11d). The Cobo granite GS8 has a

408 concave-up pattern and a negative Eu anomaly.

\subsection{Isotopes}

411

The Sr and Nd isotopic data and analytic details are shown in Table 2. The range of

413 the NGIC ${ }^{87} \mathrm{Sr} /{ }^{86} \mathrm{Sr}$ initial ratios is very restricted $(0.7055$ to 0.7058$)$, regardless of the rock

414 type (data from Bremond d'Ars et al., 1992). In the SJIC, mafic rocks (gabbros, pegmatoids,

415 and dolerites) exhibit the most positive $\varepsilon t_{\mathrm{Nd}}$ values at $347 \mathrm{Ma}(+4.7$ to 5.9$)$ and initial $\mathrm{Sr}$ ratios

416 between 0.7039 and 0.7049 . These values are similar to those obtained by Barboni et al. 
417 (2010) on pseudo-adakites related to the SJIC ( +2.9 to +6.8 and 0.7038 to 0.7047$)$. The

418 intermediate SJIC rocks (monzogabbros, monzonites, Q-monzonites, and diorite) have less

419 positive $\varepsilon_{\mathrm{Nd}}$ values $(+2.4$ to +3.2$)$ and initial $\mathrm{Sr}$ ratios which range from 0.7043 to 0.7069 .

420 This scattering suggests that the $\mathrm{Rb}$-Sr system was not closed. The granite sample SJ22 also

421 exhibits a positive $\varepsilon \mathrm{t}_{\mathrm{Nd}}$ value at $347 \mathrm{Ma}(+3.0)$ and a low initial $\mathrm{Sr}$ ratio $(<0.700)$ which also

422 shows open system behavior for Rb-Sr. A noticeable feature is the sharp isotopic contrast

423 between the Poul Rodou gabbro SJ34a $(+5.9)$ and the dioritic sheet SJ34c $(+2.6)$, two

424 neighbor samples separated by c. $3 \mathrm{~m}$ (Fig. $3 \mathrm{a}$ and 8 ).

425 It follows that the gabbro and the leucocratic sheets from Poul Rodou are not

426 cogenetic. The source of the former corresponds to that of the doleritic dykes and peripheral

427 pegmatoids, whereas the Poul Rodou sheets (and diapirs) have an isotopic composition

428 comparable to that of the other SJIC intermediate rocks.

\section{6. Discussion}

6.1. A review

\section{6.1.1. MASLI-type reservoirs: the models}

435 Wiebe and others have defined the concept of MASLI and studied many examples of 436 such intrusions, especially in Maine. A MASLI petrologically corresponds to a composite 437 layered sequence of alternating gabbroic and dioritic units situated between or below granitic 438 bodies (Chapman and Rhodes, 1992; Wiebe, 1996; Wiebe and Collins, 1998). Variants are

439 intrusions of bimodal gabbro-diorite (e.g., Ingonish, Cape Breton Island: Wiebe, 1974) or 440 diorite-granite (e.g., Nord-Forez, Massif Central, France: Barbarin, 1988), which display 441 some of the characteristic features of MASLIs. These complexes are interpreted to be the 
442 result of repeated mafic intrusions in a crystallizing dioritic/granitic reservoir (Wiebe, 1974, 443 1993b, 1996). This group of models is supported, among other things, by the observation of 444 pillow-like bodies of chilled gabbro in intermediate/felsic rocks (Wiebe, 1993b; Wiebe et al., 445 2001). Diorites are generally viewed either as products of fractional crystallization of the 446 gabbro, or as resident cumulates.

447 A multistep model for the Isle au Haut Maine igneous complex (Maine), similar to 448 those of Wiebe and others, was proposed by Chapman and Rhodes (1992). The model 449 accounts for the formation of a layered sequence of ten alternating (tholeiitic) gabbroic and 450 dioritic units of magmas, which were contemporaneous. The bases of the gabbros are chilled 451 against the underlying diorites. The authors state that mafic liquids were periodically

452 emplaced into a silicic magma chamber at the rheological transition from a relatively felsic 453 cumulate to an overlying felsic magma. Each gabbroic unit is injected below a dioritic liquid, 454 but above a solidifying dioritic crystal mush, as expected from the magma density contrast. 455 Once emplaced, crystallization progresses in the underlying dioritic mush and produces Q456 monzodioritic sheets and pipes, which intrude the gabbroic layer. Diapirs are subsequently 457 produced from the crystallizing sheets.

458 The development of such gravity-driven instabilities in layered magmas have been 459 modeled and applied to the NGIC (Bremond d'Ars, 1990; Bremond d'Ars and Davy, 1991). 460 However, according to these authors, it is not clear whether the sheets in the NGIC result 461 from intrusions within the gabbros, or the reverse. The opinion of Wiebe (1993b) is that "the

462 'veins' in Guernsey have textures and compositions that are appropriate for feldspar

463 cumulates, not solidified liquids". He views the NGIC as a crystallizing intermediate/felsic 464 reservoir periodically invaded by mafic liquids.

\subsubsection{Cumulates and pegmatoids}


The connection between mafic cumulates, gabbroic pegmatites (pegmatoids) and

aplites has been established by many authors. For instance, Beard and Day (1986) published a

469 thorough study of such rocks in the Smartville intrusive complex, Sierra Nevada, California.

470 They pointed out the following features: (i) the pegmatoids occur as pods and segregations in

471 gabbroic rocks; (ii) they are often found in association with fine-grained aplite of similar

472 mineral assemblage; and (iii) they have a very mafic composition, as observed by other

473 authors (e.g., McBirney and Noyes, 1979). Contrary to previous authors who proposed

474 subsolidus processes (e.g., Bow et al., 1982), Beard and Day (1986) favour that rocks form by

475 in situ crystallization. They envisage that a mafic intercumulus melt is extracted from a

476 cumulate stack in the presence of a fluid phase. The process could be enhanced by the

477 disruption of the cumulate assemblage due to a drop in the confining pressure. This model is

478 consistent with the one proposed by Momme and Wilson (2002) for the Kraemer Island

479 macrodyke, Greenland. It is also similar to the model of pegmatoid formation in thick basaltic

480 lava flows proposed by Caroff et al. (1997). An alternative model suggests that the pegmatoid

481 crystals grew by reaction between primary mafic mineral grains and a superheated liquid

482 possibly resulting from a pressure drop (Cawthorn and Boerst, 2006). In a plumbing system

483 connected to the surface, a pressure drop can easily be achieved subsequent to an eruption. In

484 an intrusion, confined at depth within deformable host rocks, only a volumetric expansion of a

485 constant mass plumbing system could also induce a pressure drop.

6.2. Layering and diapirism in the SJIC and NGIC

Both SJIC and NGIC display comparable characteristics, which justifies the present

490 combined study: (1) both intrusions are triple-component MASLIs (gabbro, diorite and

491 granite); (2) pegmatoids occur in association with mafic cumulates, especially at the edges of 
492 both complexes; (3) a lateral or basal part of the intrusions is formed by gabbroic sequences

493 interlayered with dioritic sheets producing diapirs. Nevertheless, numerous contrasted features

494 lead us to propose two different models for the construction of the gabbro-dioritic layered

495 sequences.

496

\subsubsection{Melagabbros and gabbros}

Two noticeable features of the NGIC gabbro-dioritic unit not observed in the SJIC are

499 the presence of macrorhythms and modal layering within the gabbroic sequences. This

500 petrological heterogeneity induces geochemical variations (Fig. 9 and 11c) and suggests

501 crystal accumulation. By contrast, the tholeiitic Poul Rodou gabbro (SJIC) is relatively

502 homogeneous (Fig. 11a). Therefore, it is probably not a cumulate, but was rather a liquid that

503 crystallized in situ without significant crystal settling, possibly after a period of convection.

504 For instance, Philpotts et al. (1996) have shown that tholeiitic magmas, when only one-third

505 crystallized, can form crystal mushes dominated by thin laths of plagioclase and elongated

506 pyroxene grains. In such magmas, an interlocking network of crystals can form at low solid

507 content (possibly only $20 \%$ ), precluding any further convection and crystal settling. Such a

508 model is consistent with both the tholeiitic affinity of the Saint-Jean gabbro (Fig. 10) and the

509 rock textures, which are intergranular to oikocrystic. On the contrary, the rhythmic sequences

510 of the calc-alkaline NGIC, and the orthocumulate texture fit with a crystal accumulation

511 model.

512 In Fig. 12, we propose two models to explain the formation of the gabbro-dioritic

513 layered sections of the SJIC and NGIC. The Poul Rodou gabbro is purported to be a simple

514 network-type crystal mush, crystallizing from the base up (Fig. 12a, b, c). In Beaucette, each

515 melagabbro/gabbro pair is asserted to correspond to a mafic recharge (Fig. 12d, g), having

516 undergone two successive crystal-settling events. At first, settling involves only mafic crystals 
517 (olivine, pyroxene \pm primary hornblende: Fig. 12e) and next, plagioclase appears on the

518 liquidus (Fig. 12f). In the first step, densities of the mafic crystals are comparable and the

519 resulting cumulate is highly mafic and texturally homogeneous (melagabbroic unit). With the

520 appearance of plagioclase, the density difference between feldspar and mafic crystals can

521 produce alternating dark/mesocratic layers (gabbroic unit), according to the model of Sparks

522 et al. (1993).

6.2.2. Formation of leucocratic sheets and diapirs

Models of dioritic/monzonitic reservoirs periodically replenished by mafic liquids

526 hardly apply to all the stages of construction of both intrusions.

In the SJIC, observations supporting the idea that intermediate magmas have invaded mafic ones include: (1) the several sheets of intermediate composition that we interpret as intrusions in the Poul Rodou homogeneous gabbro; (2) the monzonitic dykes throughout most

530 of Saint-Jean's bay, especially those including angular mafic breccias (Fig. 4c); (3) the lack of 531 evidence for chilling of the Poul Rodou gabbro against the dioritic sheets (Fig. 8); and (4) the 532 large predominance of the gabbroic rocks over the whole intrusion. We do not exclude that 533 mafic inputs, at huge rates, possibly inducing intensive thermal rejuvenation of a more felsic 534 resident magma, were previously involved in the SJIC. We mean here that, as observed today, 535 (1) and (2) are unlikely the direct, in situ or slightly displaced, remnants of an initial felsic 536 reservoir that remains rather hypothetical from (3) and (4). The chilled gabbroic pillow-like enclaves, such as those of Fig. 4a, result from

538 fragmentation of mafic magmas in more felsic ones. Such a mingling is controlled by 539 rheological contrasts and/or surface energy and depends on the relative volumes and 540 temperatures of available magmas (e.g., Sparks and Marshall, 1986; Fernandez and Barbarin, 541 1991; Hallot et al., 1996; Pons et al., 2006). Thus, it can be achieved during or just after new 
542 mafic inputs, but may alternatively result from convective motions in the interior of a large

543 composite reservoir or from injections of an external more felsic magma into a resident mafic

544 magma. Chilling of the latter just requires significant volumes of colder, but still mobile,

545 more felsic magmas.

546 Therefore, we propose a model of a reservoir repeatedly replenished by dioritic

547 magmas for the SJIC. Those magmas were not genetically related, nor had they to be initially

548 at the same temperature. In the reservoir, the gabbroic magma density increases downward

549 with cooling, hence crystallinity. Andesites/diorites and basalts/gabbros may have comparable

550 densities, especially when they are of tholeiitic affinity (e.g., Sparks et al., 1980; Sparks and

551 Huppert, 1984; Caroff, 1995). A partly crystallized dioritic magma rising through a tholeiitic

552 gabbro crystallizing from below is thus expected to be buoyant initially, then at neutral

553 buoyancy and finally denser than the gabbroic magma. In Fig 12a and b, a $950^{\circ} \mathrm{C}$ dioritic

554 magma with $30 \%$ plagioclase phenocrysts enters a gabbroic reservoir crystallizing from

555 below. At the base (1), the gabbroic magma is $70 \%$ solid at $1100^{\circ} \mathrm{C}$. At upper levels (2) and

556 (3), it is $30 \%$ solid at $1150^{\circ} \mathrm{C}$ and liquid at $1200^{\circ} \mathrm{C}$, respectively (all values are approximates).

557 Reaction kinetics being much slower than heat transfer, a metastable dioritic melt plus

558 crystals at thermal equilibrium with the resident magma is considered at these levels.

559 Densities were estimated given that the density of a liquid, obtained from Bottinga and Weill

560 (1970), is about $90 \%$ of that of its solid equivalent and assuming that this ratio applies to the

561 solid fraction whatever it is (Fig. 12). The results show that at levels (1) and (2), a gabbroic

562 magma remains denser than a dioritic magma. At level (3), equidensity is reached allowing a

563 dioritic magma to spread out, forming sheets. Thus, we interpret each SJIC sheet as the result

564 of some horizontal emplacement of porphyric magmas of intermediate composition into

565 poorly crystallized gabbros at levels of neutral buoyancy. Late felsic diapirs formed at the top

566 of emplaced sheets while the equidensity front moved upward as cooling proceeded (Fig. 12b 
and c). In situ fractionation within the sheets favored the late production of low density magmatic liquids. The REE patterns of the diapirs are depleted in HREE with respect to the sheets from which they were extracted (Fig. 11a). This is consistent with fractionation of a

570 significant amount of amphibole within the sheets. Indeed, amphibole preferentially

571 incorporates middle to heavy REE relative to LREE (e.g., Caroff et al., 1999).

In the NGIC, dioritic sheet and vein geometries are controlled by the macrorhythms:

573 the pipe-producing sheets are generally located along the lower boundary of the melagabbroic

574 units and the cross-connected dioritic vein network forms in the gabbroic units according to

575 the framework of the dark/mesocratic layers. These features suggest that the gabbroic

576 structures existed prior to the dioritic veining. The fine-grained margins at the base of

577 melagabbroic units relate to mafic replenishments before the dioritic invasion.

The main similarity between the SJIC and the NGIC was the late influx of the dioritic

579 magmas with respect to the main gabbroic magmas. At Beaucette, both magmas were close to

580 isotopic equilibrium. The emplacement of the dioritic sheets was not directly controlled by

581 density ratios, but rather by pre-existent rhythmic structures within cumulates (Fig. 12h). Two

582 groups of sheets have to be distinguished. An initial gabbroic to dioritic magma was emplaced

583 just beneath the base of the melagabbroic units (Fig. 5a, c). The sheet-derived pipes cut across

584 the melagabbroic unit (Fig. 5b), until the overlying gabbroic unit. The concave-up shape of

585 the REE pattern of the pipe GS10c (Fig. 11c) is consistent with crystallization and

586 fractionation of both amphibole and apatite in its parental sheet (Caroff et al., 1999). Relative

587 motions between the unconsolidated/mushy units possibly caused the vertical pipes to become

588 inclined (Fig. 5e, 12i), as previously proposed by Elwell et al. (1960). They might have

589 created proto-fissures in the gabbroic unit and thus have favored the emplacement of the

590 (monzo)dioritic second group of sheets, which are cross-connected and fed by the pipes (Fig.

$5915 \mathrm{~d}, 12 \mathrm{i})$. The gabbroic layering, seen as controlling the architecture of the cross-connected 
592 vein/sheet network, supports our interpretation of late dioritic invasion within gabbros.

593 Cumulative features of the sheets reveal that the invading magmas possibly contained

594 plagioclase phenocrysts, such as those in the SJIC.

\subsection{Variations in the mode of MASLI construction}

Our models (Fig. 12) agree with the general physical conditions and the mechanisms

599 by which layers, pipes, diapirs and other plutonic structures are supposed to form within

600 crystallizing magmas (e.g., see Barbey, 2009 and Patterson, 2009 and references therein for

601 recent reviews). In our opinion, the SJIC and the NGIC support the general idea that

602 intermediate/felsic replenishment of a mafic reservoir is a situation much more common than

603 previously thought, though not as common as mafic replenishment.

Bremond d'Ars et al. (1992) have proposed a sketchy model of the NGIC reservoir.

According to these authors, the layered rocks (Saint-Peter Port cumulate and Beaucette-type gabbro-diorite) formed near the margin of the chamber, by upwards prograding crystallization and replenishments. The present dip of the layers is primary. Far from the margins, the centre

610 of the reservoir was probably convective, which explains the lack of layering in most of the

611 Bordeaux gabbro-diorite outcrops, with the exception of Beaucette. The peripheral granitic

612 bodies (Cobo, L'Ancresse) are proposed to form by mixing and assimilation of crust-derived

613 melts with the gabbro-diorite magmas. Large volumes of mafic magma are thought to have

614 induced melting of country rocks at depth within the plumbing system. We agree with the basic ideas of this model, except for the the hypothesis of crustal

616 melting. Although interactions between gabbro-dioritic and granitic rocks are undeniable 
617 (Topley et al., 1982; D'Lemos, 1996), available isotopic data seems hardly consistent with

618 crustal melting (Table 2). We rather suggest, as D'Lemos (1996), that at least the Cobo

619 granite is to a great extent cogenetic with the Bordeaux gabbro-diorite, as it is often observed

620 in MASLIs (e.g., Wiebe, 1993a, b, 1994, 1996; Wiebe and Collins, 1998).

621 An-rich plagioclases in both the mottled cumulate GS1a from Spur Point and the

622 gabbroic sheet sample GS13a from Beaucette support the hypothesis that the invading dioritic

623 liquid(s) originate(s) from the mottled Saint-Peter-Port/Spur Point cumulate, interpreted as a

624 boundary layer by Bremond d'Ars et al. (1992). An-rich plagioclase cores (An>75, Fig. 7b)

625 suggest crystallization under hydrous conditions (Cordier et al., 2007). Derivation of a

626 GS13a-type composition from a liquid leaving a GS1a-type cumulate is also supported by

627 trace element compositions. Indeed, cross-cutting REE curves in Fig. 11d possibly reflect

628 crystal fractionation/accumulation (plagioclase, amphibole and/or apatite).

A model of the SJIC is drawn in Fig. 13.

633 the gabbro-dioritic magmas.

Pegmatoids and associated mafic cumulates are located near the edge of the complex

635 (Fig. $1 \mathrm{~b}$ and $2 \mathrm{~b}, \mathrm{c}$ ). With an isotopic composition close to that of the Poul Rodou gabbro and

636 the doleritic dykes, but more mafic, pegmatoids likely correspond to liquids issued from a

637 mafic intercumulus melt in the presence of a fluid phase. Melt extraction might have been

638 enhanced by the disruption of the cumulate stack, perhaps in a context of drop of the confining pressure (Beard and Day, 1986; Momme and Wilson, 2002). Reactions of the liquid

640 with primary mafic minerals of the cumulate might explain $\mathrm{Mg}$-rich pegmatoid compositions

641 (Cawthorn and Boerst, 2006). 
Mixing and mingling seem to have preferentially occurred in the central part of the

643 reservoir. Dionitic liquids (in a broad sense) mix with gabbroic magmas to form variable

644 hybridized products, the isotopic composition of which tends toward that of the diorites. The

645 most homogeneous hybridized product, which has a dioritic isotopic signature (Table 2),

646 corresponds to the Saint-Jean's bay monzogabbro. Such an isotopic homogenization in a

647 MASLI, by mixing and diffusion (Steward and De Paolo, 1992), has already been described

648 by Waight et al. (2007). Angular breccias, also drawn in Fig. 13, can result either from

649 gabbro/diorite interactions in a more peripheral (i.e. colder) region of the reservoir, or,

650 alternatively, from late arrivals of dioritic liquids in a solidifying magma. The ductile to brittle

651 behavior of a magma which can be inferred from the preserved shapes of the enclaves also

652 depends on the strain rates involved during fragmentation (Fernandez and Gasquet, 1994;

653 Hallot et al., 1996; Petford, 2009).

654 At Poul Rodou, the isotopic composition of the felsic sheets differs from that of the

655 enclosing resident gabbro. The SJIC intermediate and felsic products are therefore issued

656 from a source which is different from that of the Poul Rodou gabbro / Primel pegmatoid /

657 Saint-Jean dolerite group. An AFC-type crustal contamination of the felsic liquid in a deep

658 reservoir possibly accounts for such features.

660 7. Conclusions

(1) The Saint-Jean-du-Doigt (SJIC) and the North-Guernsey (NGIC) Intrusive

663 Complexes are two MAfic-Silicic Layered Intrusions (MASLI) of the armorican Massif. Both

664 are triple component complexes (gabbro, diorite, granite) characterized by the occurrence of

665 pegmatoids in association with cumulates and of gabbroic units including diapir-producing 
666 dioritic sheets. The NGIC is Cadomian and calc-alkaline. Mafic rocks of the Hercynian SJIC 667 are tholeiitic.

668 (2) Pegmatoids are interpreted as liquids extracted from a mafic intercumulus melt in 669 the presence of a fluid phase, subsequent to the disruption of a peripheral cumulate stack, 670 possibly during a drop of the confining pressure.

671 (3) At least at some stages, the gabbro-dioritic units of the SJIC and the NGIC can

672 both result from repeated influxes of magmas of intermediate composition within mafic

673 reservoirs, but they are built differently. The SJIC gabbro could result from in situ

674 crystallization of a relatively uniform magma in which crystal settling was not significant.

675 Assuming they were metastable, dioritic magmas could have risen as gravity-driven diapirs in 676 such a crystallizing gabbro before they spread to form sheets at levels of neutral buoyancy. By

677 contrast, the NGIC gabbros correspond to cumulates. At Beaucette, they display a rhythmic

678 layering which has guided the subsequent dioritic injections.

679

680 Acknowledgements

We are grateful to P.-M. Le Dantec for field assistance (Primel and Roc'h Louet

682 cartography). Detailed and constructive comments by Dr P. Barbey and an anonymous

683 reviewer helped us to improve the manuscript. Pertinent suggestions of A. Brink are

684 gratefully acknowledged. We also thank Dr C.G. Barnes for discussions and Dr N. Eby for

685 editorial assistance.

687 References 
Auvray, B., Charlot, R., Vidal, P., 1980. Données nouvelles sur le protérozoïque inférieur du domaine nord-armoricain (France) : âge et signification. Canadian Journal of Earth Sciences 17, 532-538.

Barbarin, B., 1988. Field evidence for successive mixing and mingling between the Piolard Diorite and the Saint-Julien-la-Vêtre Monzogranite (Nord-Forez, Massif Central, France). Canadian Journal of Earth Sciences 25, 49-59.

Barbey, P., 2009. Layering and schlieren in granitoids: a record of interactions between magma emplacement, crystallization and deformation in growing plutons. Geologica Belgica 12, 109-133.

Barboni, M., Bussy, F., Schoene, B., Schaltegger, U., 2008. Architecture and emplacement mechanism of the Saint Jean du Doigt bimodal intrusion, Brittany, France. Geophys. Res. Abstr. 10, EGU2008-A-05182.

Barboni, M., Bussy, F., Chiaradia, M., 2010. Origin of Early Carboniferous pseudo-adakites in northern Brittany (France) through massive amphibole fractionation from hydrous basalt. Terra Nova, doi:10.1111/j.1365-3121.2010.00974.x.

Beard, J.S., Day, H.W., 1986. Origin of gabbro pegmatite in the Smartville intrusive complexe, northern Sierra Nevada, California. American Mineralogist 71, 1085-1099.

Bottinga, Y., Weill, F., 1970. Densities of liquid silicate systems calculated from partial molar volumes of oxide components. American Journal of Science 269, 169-182.

Bow, C., Wolfgram, D., Turner, A., Barnes, S., Evans, J., Zdepski, M., Boudreau, A., 1982. Investigations of the Howland reef of the Stillwater Complex, Minneapolis adit area : stratigraphy, structure, and mineralization. Economic Geology 77, 1481-1492.

Bremond d'Ars, J. de, 1990. Estimation des propriétés rhéologiques des magmas par l'étude des instabilités gravitaires. Pétrologie du complexe plutonique de Guernesey. Mémoires 
et Documents du Centre Armoricain d'Etude Structurale des Socles (Thesis), Rennes 35, $370 \mathrm{p}$.

715 Bremond d'Ars, J. de, Davy, P., 1991. Gravity instabilities in magma chambers - rheological modeling. Earth and Planetary Science Letters 105, 319-329.

717 Bremond d'Ars, J. de, Martin, H., Auvray, B., Lécuyer, C., 1992. Petrology of a magma chamber: the plutonic complex of Guernsey (Channel Islands, UK). Journal of the

Briden, J.C., Clark, A., Fairhead, J.D., 1982. Gravity and magnetic studies in the Channel

Cabanis, B., Lecolle, M., 1989. Le diagramme La/10-Y/15-Nb/8: un outil pour la discrimination des séries volcaniques et la mise en évidence des processus de mélange et/ou de contamination crustale. Comptes Rendus de 1'Académie des Sciences de Paris

730 Caroff, M., Ambrics, C., Maury, R.C., Cotten, J., 1997. From alkali basalt to phonolite in 309, série II, 2023-2029.

Capdevila, R., 2010. Les granites varisques du Massif armoricain. Bulletin de la Société Géologique et Minéralogique de Bretagne (D) 7, 1-52.

Caroff, 1995. Open system crystallization and mixing in two-layer magma chambers. Lithos $36,85-102$.

736 Cawthorn, R.G., Boerst, K., 2006. Origin of the pegmatitic pyroxenite in the Merensky Unit, 737 Bushveld Complex, South Africa. Journal of Petrology 47, 1509-1530. 
Chantraine, J., Chauris, L., Cabanis, B., Chauris, M.-M., Larsonneur, C., Herrouin, Y., Rabu, D., Lulzac, Y., Bos, P., 1986. Notice explicative, carte géol. France (1/50 000), feuille Plestin-Les-Grèves (202). Orléans, BRGM, 84 p. Geological map by J. Chantraine et al. (1985).

Chapman, M., Rhodes, J.M., 1992. Composite layering in the Isle au Haut Maine igneous complex, Maine: Evidence for periodic invasion of a mafic magma into an evolving magma reservoir. Journal of Volcanology and Geothermal Research 51, 41-60.

Coint, N., Caroff, M., Hallot, E., Peucat, J.J., 2009. The gabbro-diorite layered intrusions of Saint-Jean-du-Doigt (France) and Beaucette (Guernsey, Channel Island), Armorican Massif: an emplacement model. Geological Society of America Abstracts with Programs $41(2), 30$.

Coint, N., Hamelin, C., Caroff, M., 2008. Le complexe gabbro-dioritique lité de Saint-Jeandu-Doigt, Massif armoricain: un exemple de réservoir magmatique de type MASLI. Bulletin de la Société Géologique et Minéralogique de Bretagne (D) 5, 1-29.

Collins, W.J., Wiebe, R.A., Healy, B., Richards, S.W., 2006. Replenishment, crystal accumulation and floor aggradation in the megacrystic Kameruka suite, Australia. Journal of Petrology 47, 2073-2104.

Cordier, C., Caroff, M., Juteau, T., Fleutelot, C., Hémond, C., Drouin, M., Cotten, J., Bollinger, C., 2007. Bulk-rock geochemistry and plagioclase zoning in lavas exposed along the northern flank of the Western Blanco Depression (Northeast Pacific): Insight into open-system magma chamber processes. Lithos 99, 289-311.

Cotten, J., Le Dez, A., Bau, M., Caroff, M., Maury, R., Dulski, P., Fourcade, S., Bohn, M., Brousse, R., 1995. Origin of anomalous rare-earth element and yttrium enrichments in subaerial exposed basalts: Evidence from French Polynesia. Chemical Geology 119, 115-138. 
De Paolo, D.J., 1988. Neodymium isotope geochemistry, an introduction. Mineral and rocks, 20. Springer Verlag, Berlin, Heidelberg.

D’Lemos, R.S., 1996. Mixing between granitic and dioritic crystal mushes, Guernsey, Channel Islands, UK. Lithos 38, 233-257.

Elwell, R.W.D., Skelhorn, R.R., Drysdall, A.R., 1960. Inclined granitic pipes in the diorites of Guernsey. Geological Magazine 97, 89-105.

Elwell, R.W.D., Skelhorn, R.R., Drysdall, A.R., 1962. Net veining in the diorite of north east Guernsey, Channel Islands. Journal of Geology 70, 215-226.

Fernandez, A.N., Barbarin, B., 1991. Relative rheology of coeval mafic and felsic magmas : Nature of resulting interaction processes and shape and mineral fabrics of mafic microgranular enclaves. In: Didier, J., Barbarin, B. (Eds), Enclaves and granite

Fernandez, A.N., Gasquet, D.R., 1994. Relative rheological evolution of chemically contrasted coeval magmas: example of the Tichka plutonic complex (Morocco). Contributions to Mineralogy and Petrology 116, 316-326.

Graviou, P, Auvray, B., 1985. Caractérisation pétrographique et géochimique des granitoïdes cadomiens du domaine nord-armoricain: implications géodynamiques. Comptes Rendus de 1'Académie des Sciences de Paris 301, 315-318. newtonian effects during injection in partially crystallized magmas. Journal of Volcanology and Geothermal Research 71, 31-44. 
Hellström, F.A., Johansson, A., Larson, S.A., 2004. Age and emplacement of late Sveconorwegian monzogabbroic dykes, SW Sweden. Precambrian Research 128, 39-55.

Johnson, M.C., Rutherford, M.J., 1989. Experimental calibration of the aluminium-inhornblende geobarometer with application to Long Valley caldera (California) volcanic rocks. Geology 17, 837-841.

La Roche, H. de, Leterrier, J., Grandeclaude, P., Marchal, M., 1980. A classification of volcanic and plutonic rocks using R1R2-diagrams and major-element analyses - its relationships with current nomenclature. Chemical Geology 29, 183-210.

López-Moro, F.J., López-Plaza, M., 2004. Monzonitic series from the Variscan Tormes Dome (Central Iberian Zone): petrogenetic evolution from monzogabbro to granite magmas.

McBirney, A.R., Noyes, R.M., 1979. Crystallization and layering of the Skaergaard intrusion. Journal of Petrology 20, 487-554.

McEllen, A.T., 2006. Pegmatites of the Mount Sheridan gabbro, Wichita Mountains, Oklahoma. Geological Society of America Abstracts with Programs 38 (1), 5.

Momme, P., Wilson, J.R., 2002. The Kraemer Island macrodyke, East Greenland: solidification of a flood basalt conduit. Geological Magazine 139, 171-190.

804 Paterson, S.R., 2009. Magmatic tubes, pipes, troughs, diapirs, and plumes: Late-stage convective instabilities resulting in compositional diversity and permeable networks in crystal-rich magmas of the Tuolumne batholith, Sierra Nevada, California. Geophere 5,

Petford, N., 2009. Which effective viscosity? Mineralogical Magazine 73, 167-191. the East-Antarctica shield: geological and isotopic evidence for a major $1.7 \mathrm{Ga}$ thermal 
event; comparison with the Gawler Craton in South Australia. Precambrian Research 94, 205-224.

813 Philpotts, A.R., Carroll, M., Hill, J.M., 1996. Crystal-mush compaction and the origin of pegmatitic segregation sheets in a thick flood-basalt flow in the Mesozoic Hartford Basin, Connecticut. Journal of Petrology 37, 811-836.

816 Pons, J., Barbey, P., Nachit, H., Burg, J.-P., 2006. Development of igneous layering during growth of pluton: The Tarçouate Laccolith (Morocco). Tectonophysics 413, 271-286.

Roach, R.A., 1971. The layered structure of the St Peter Port Gabbro, Guernsey, Channel Isles (abstract). Journal of the Geological Society of London 127, 295.

Samson, S.D., D'Lemos, R.S., 1998. U-Pb geochronology and Sm-Nd isotopic composition of Proterozoic gneisses, Channel Islands, UK. Journal of the Geological Society of

823 Samson, S.D., D'Lemos, R.S., 1999. A precise late Neoproterozoic U-Pb zircon age for the

Sparks, R.S.J., Huppert, H.E., Koyaguchi, T., Halloworth, M.A., 1993. Origin of modal and rhythmic igneous layering by sedimentation in a convecting magma chamber. Nature $361,246-249$. 
835 Sparks, R.S.J., Marshall, L.A., 1986. Thermal and mechanical constraints on mixing between mafic and silicic magmas. Journal of Volcanology and Geothermal Research 29, 99-124.

837 Sparks, R.S.J., Meyer, P., Sigurdsson, H., 1980. Density variation amongst Mid-Ocean Ridge Basalts: implication for magma mixing and the scarcity of primitive lavas. Earth and

Stewart, B.W., De Paolo, D.J., 1992. Diffusive isotopic contamination of mafic magma by coexisting silicic liquid in the Muskox intrusion. Science 255, 708-711.

842 Sun, S.S., McDonough, W.F., 1989. Chemical and isotopic systematics of oceanic basalts: implication for mantle composition and processes. In: Saunder, A.D., Norry, M.J. (Eds),

Topley, C.G., Brown, M., Power, G.M., 1982. Interpretation of field relationships of diorites and associated rocks with particular reference to northwest Guernsey, Channel Islands. Geological Journal 17, 323-343.

Waight, T.E., Wiebe, R.A., Krogstad, E.J., 2007. Isotopic evidence for multiple contributions to felsic magma chambers: Gouldsboro Granite, Coastal Maine. Lithos 93, 234-247. Journal of Geology 82, 74-87.

857 Wiebe, R.A., 1993a. Basaltic injections into floored silicic magma chambers. Eos, Transactions, American Geophysical Union 74, 1, 3. 
859 Wiebe, R.A., 1993b. The Pleasant Bay layered gabbro-diorite, Coastal Maine: Ponding and crystallization of basaltic injections into a silicic magma chamber. Journal of Petrology $34,461-489$.

Wiebe, R.A., 1994. Silicic magma chambers as traps for basaltic magmas: The Cadillac Mountain intrusive complex, Mount Desert Island, Maine. Journal of Geology 102, 423 437.

Wiebe, R.A., 1996. Mafic-silicic layered intrusions: the role of basaltic injections on magmatic processes and the evolution of silicic magma chambers. Transactions of the Royal Society of Edinburgh: Earth Sciences 87, 233-242.

Wiebe, R.A., Collins, W.J., 1998. Depositional features and stratigraphic sections in granitic plutons: implications for the emplacement and crystallization of granitic magma. Journal

Wiebe, R.A., Frey, H., Hawkins, D.P., 2001. Basaltic pillow mounds in the Vinalhaven intrusion, Maine. Journal of Volcanology and Geothermal Research 107, 171-184.

Wiebe, R.A., Smith, D., Sturm, M., King, E.M., Seckler, M.S., 1997. Enclaves in the Cadillac Mountain Granite (Coastal Maine): Samples of hybrid magma from the base of the chamber. Journal of Petrology 38, 393-423.

Wiebe, R.A., Wark, D.A., Hawkins, D.P., 2007. Insights from quartz cathodoluminescence zoning into crystallization of the Vinalhaven granite, coastal Maine. Contributions to

\section{Figure captions}

882 Fig. 1. Geological sketch maps, location of detailed maps (including those of Fig. 2) and of samples. a. North Armorican domains. b. Saint-Jean-du-Doigt intrusive complex (SJIC), from 
884 Chantraine et al. (1986). Ages from Barboni et al. (2010). c. North-Guernsey intrusive

885 complex (NGIC), contours and ages from Bremond d'Ars et al. (1992) and Samson and

886 D'Lemos $(1998,1999)$.

887

888 Fig. 2. Geological sketch map of noteworthy outcrops and sample location. a. Poul Rodou, b.

889 Roc'h Louet, and c. Primel from the SJIC (this work). d. The Beaucette Battery, and e. The

890 Beaucette pass from the NGIC (this work and Bremond d'Ars et al., 1992).

891

892 Fig. 3. Photographs of sheets and diapirs in the SJIC sampled sections. a. Section SJ34 and sample position. Hammer for scale. b. Section SJ43 and sample position. Hammer for scale.

c. A dioritic sheet with feeding roots, under a xenolith. d. A concave-down diapir within the gabbro, just below a not visible dioritic sheet.

897 Fig. 4. Mixing, mingling, magmatic brecciation and pegmatoid in the SJIC (Saint-Jean's bay).

a. Gabbroic pillow-like enclave with a chilled margin, enclosed in a heterogeneous monzogabbro (mingling). b. Ribbon rocks in the process of hybridization (mingling/mixing).

900 Hammer for scale. c. Jigsaw-type breccias with polyhedral mafic enclaves enclosed in a

901 texturally homogeneous (intergranular) monzonite forming a vein network. A few blocky 902 clasts present mixing/mingling evidence (not visible). d. Mafic cumulate-aplite-pegmatoid association. Sample PM2 (three analyses in Table 1).

904

905 Fig. 5. Sheets and diapirs in the NGIC. a. Photograph of section GS10 and sample position.

906 Hammer for scale. b. Detail: gabbroic sheet and inclined pipes. Pencil for scale. c.

907 Photograph of section GS13 and sample position. d. Sketch of the dioritic veins. e. Sketch of 908 the inclined pipes. f. Cross-section through a zoned pipe, with a core (dark gray) less 
909 differentiated than the rim (light gray), a pegmatitic upper part (white), and altered overlying

910 host rock. d, e and f from Elwell et al. (1960).

911

912 Fig. 6. Cumulates and pegmatoids from the NGIC (Spur Point, Saint Peter Port gabbro). a.

913 Mottled orthocumulate showing layers of poikilitic amphibole crystal flecks. Pencil for scale.

914 b. Photomicrograph (crossed nicols) of the Spur Point mottled orthocumulate (sample GS1a,

915 fleck-free white layer). Cumulus minerals are calcic plagioclase (P1), hornblende (Hb) and

916 clinopyroxene (Cpx). By decreasing abundance, intercumulus phases are plagioclase,

917 clinopyroxene, orthopyroxene, Fe-Ti oxides, and apatite. c. Mafic cumulate-pegmatoid

918 association.

919

920 Fig. 7. NGIC plagioclase compositions. a. Anorthite content in plagioclases of samples GS1a

921 (26 analyses), GS7d, e, 1 (21 analyses), and GS13a (16 analyses). b. Anorthite profile through

922 a plagioclase from GS13a.

923

924 Fig. 8. Chemical sections in the SJIC. $\mathrm{MgO}, \mathrm{TiO}_{2}$ and $\mathrm{Al}_{2} \mathrm{O}_{3}$ concentrations through sections 925 SJ34 and SJ43 (located in Fig. 2a and shown in Fig. 3a and b). Microtextural sketches, shown

926 for samples SJ34a, d2, and e, evidence the lack of chilled margins (white: plagioclase; grey:

927 amphibole and altered olivine; black: Fe-Ti oxides).

928

929 Fig. 9. Chemical sections in the $\mathrm{NGIC} . \mathrm{MgO}, \mathrm{TiO}_{2}$ and $\mathrm{Al}_{2} \mathrm{O}_{3}$ contents through sections 930 GS10-13 and GS7 (located in Fig. 2d and e).

931

932 Fig. 10. Magmatic affinities of the mafic rocks from the SJIC and NGIC. Position of the 933 gabbroic samples in the diagram La/10-Y/15-Nb/8 (Cabanis and Lecolle, 1989). 
935 Fig. 11. Chondrite C1-normalized rare earth elements (REE) patterns of representative SJIC

936 and NGIC samples. Normalization values from Sun and McDonough (1989). a. Sheet-diapir

937 pairs SJ34 and SJ43, together with the corresponding gabbroic field (SJIC). b. Selected SJIC

938 samples. c. Macrorhythms, sheets and a pipe from the NGIC. d. Granite, sheet and cumulate

939 from the NGIC.

940

941 Fig. 12. Models of replenishment and crystallization. Time proceeds along the " $t$-box" line.

942 a. b. c. Model for Poul Rodou in the SJIC. A gabbroic ( $\theta$ ) reservoir crystallizes from below:

943 crystal settling is negligible so that the resulting gabbro is almost homogeneous. A dioritic

944 magma $(\delta)$ with about $\chi=30 \%$ phenocrysts enters the crystallizing gabbro. First buoyant at the

945 base, while rising it crosses levels of neutral buoyancy (assuming negligible crystal

946 resorption) where it spreads to form sheets from which diapirs are then extracted. $\rho$ is density

947 at given temperature (calculated from Bottinga and Weill, 1970) and crystal content ( $\chi$ for $\delta$;

948 grey scale to the right for $\theta$; see text). Insets are detailed zones of $a$ and $b$.

949 d. e. f. g. h. i. Model for Beaucette in the NGIC. Mafic recharges (d, g) and crystal settling,

950 first of mafic minerals alone (e), second of mafic crystals and plagioclase (f) account for the

951 layering and the heterogeneities of the gabbros. Then late dioritic recharges (h) and

952 subsequent evolution (i, see text) explain most of the observed features.

953

954 Fig. 13. A comprehensive model for the SJIC reservoir. The straight line locates the observed

955 Poul Rodou/Saint-Jean's bay/Primel coastal cross-section. See text for explanations. 


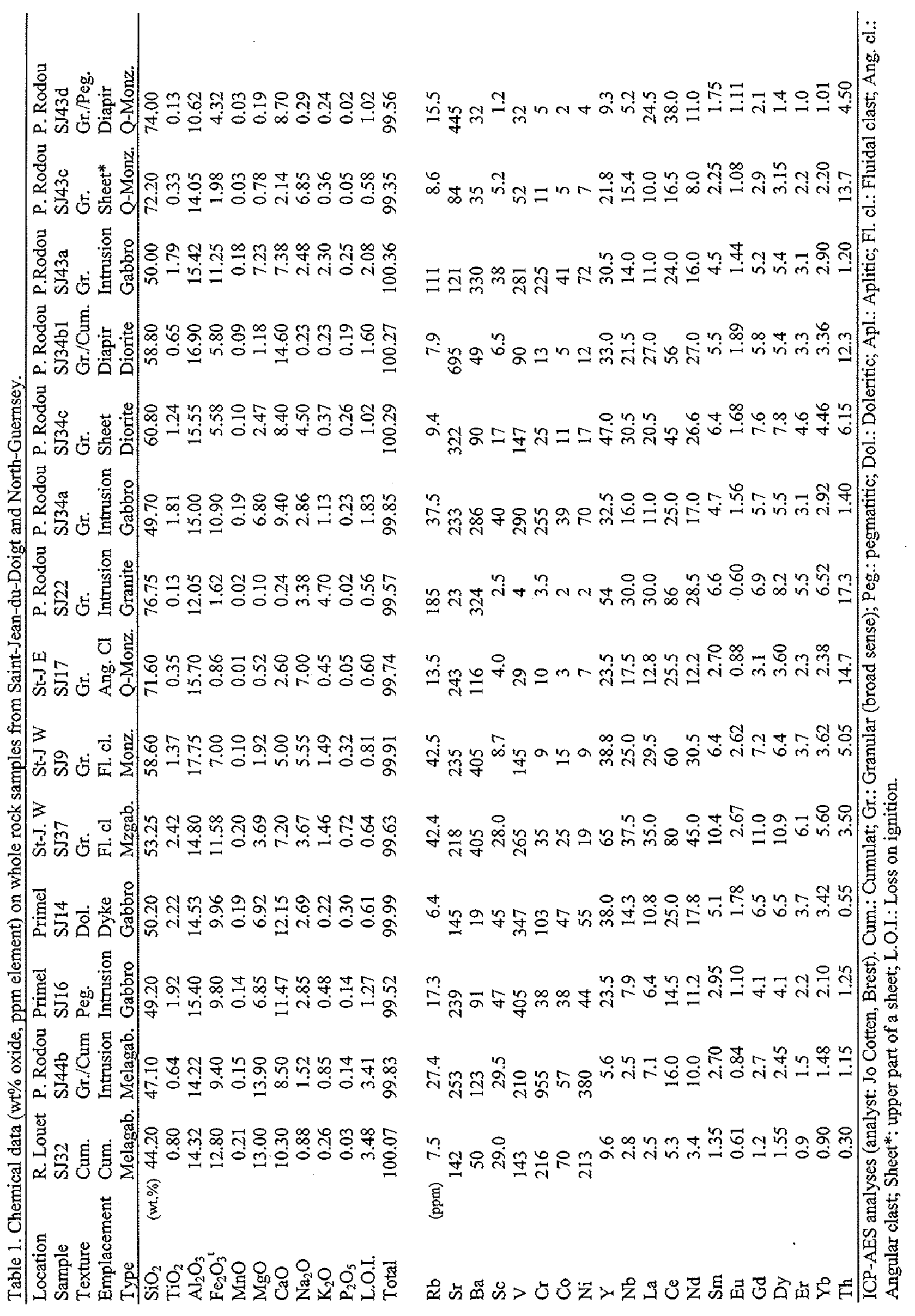




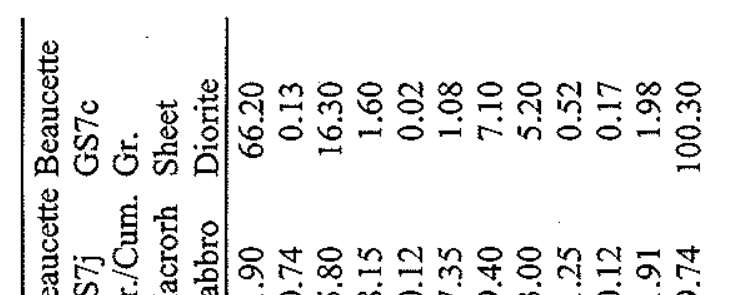

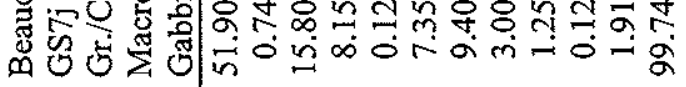

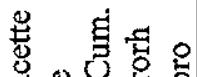

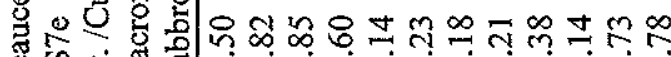

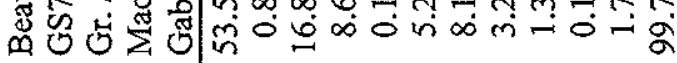

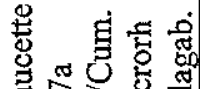

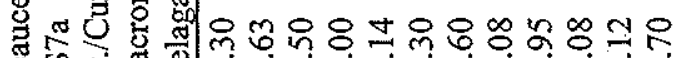

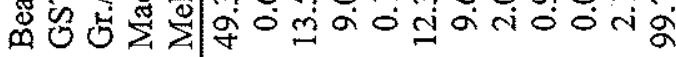
过

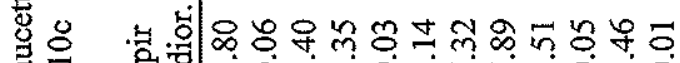

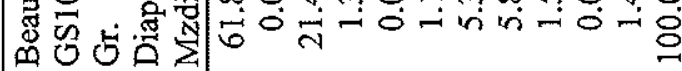
荧

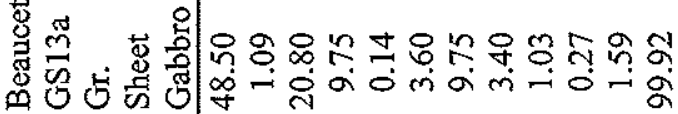
密

莺岁突

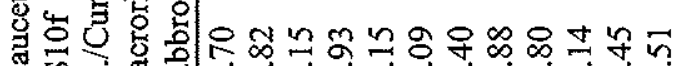

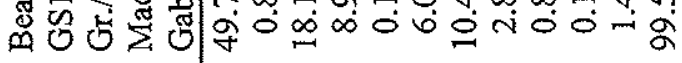

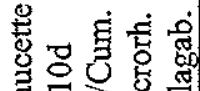

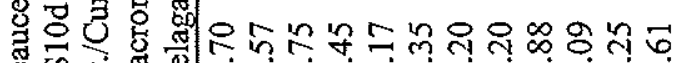

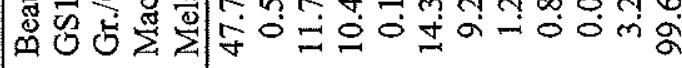

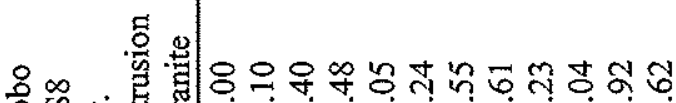

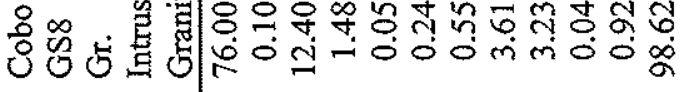

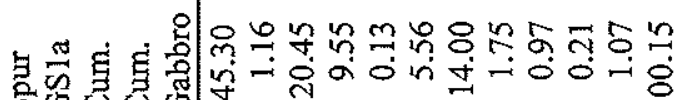

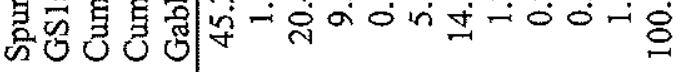

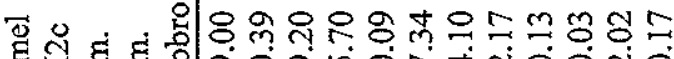

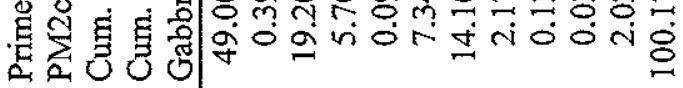

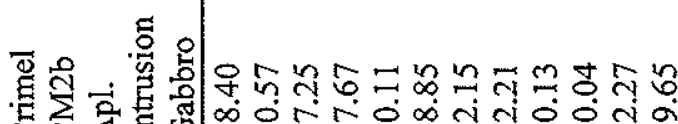

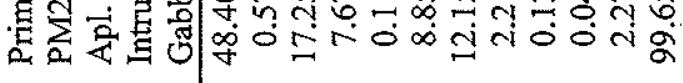

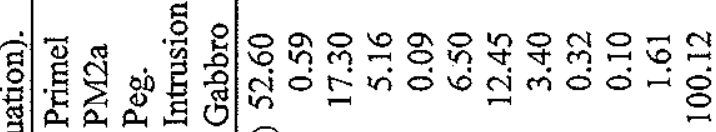

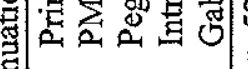

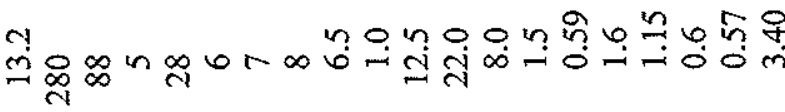

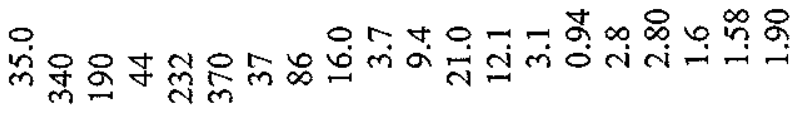

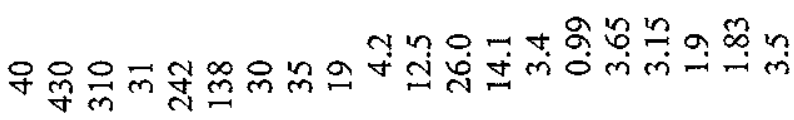

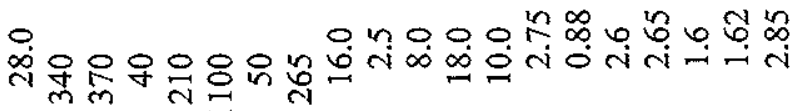

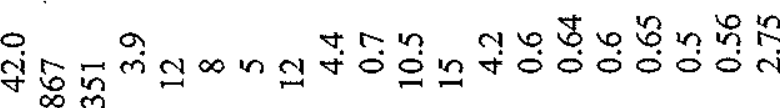

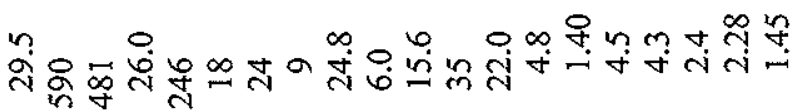

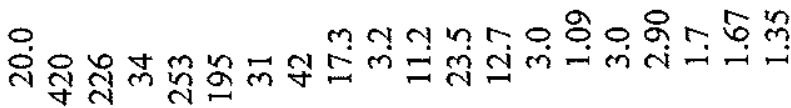

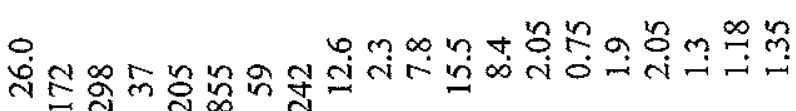

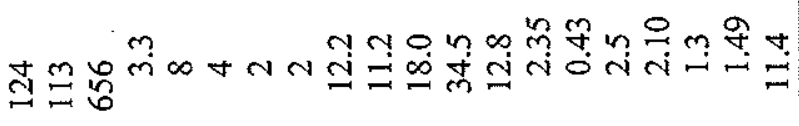

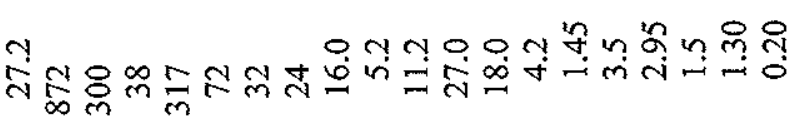

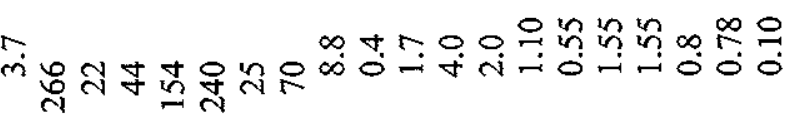

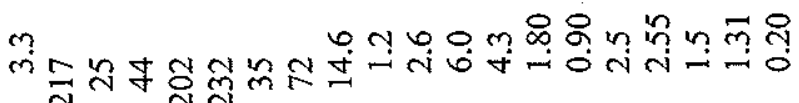

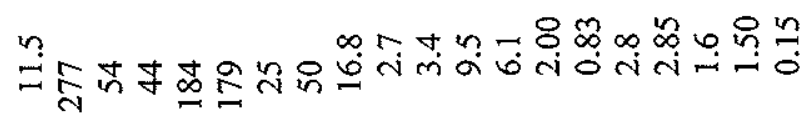
言

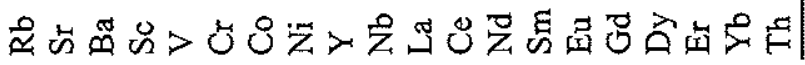




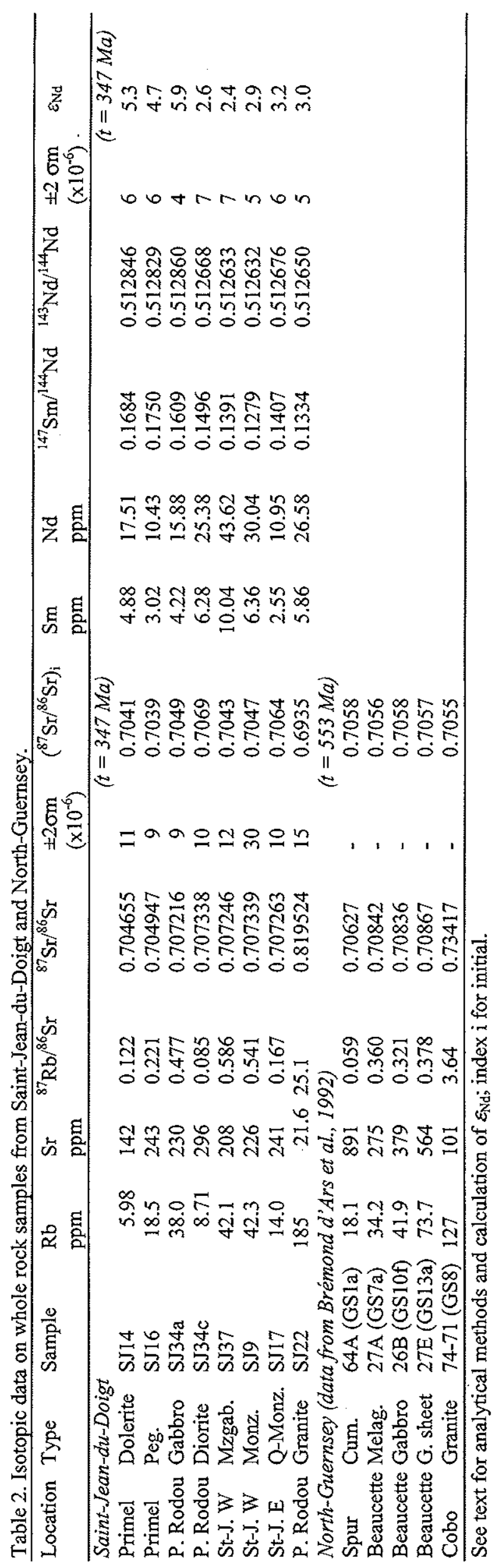




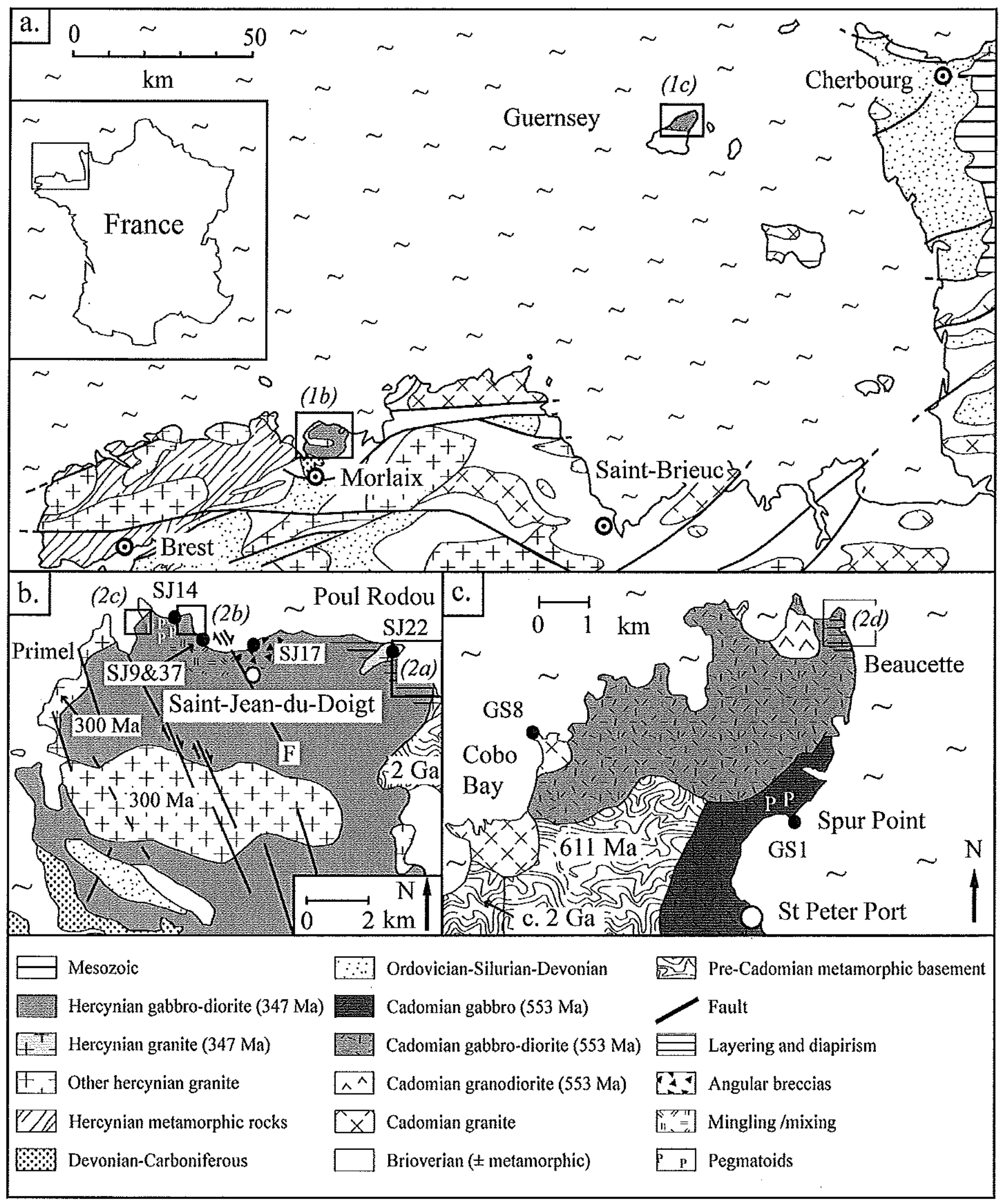

Fig. 1 


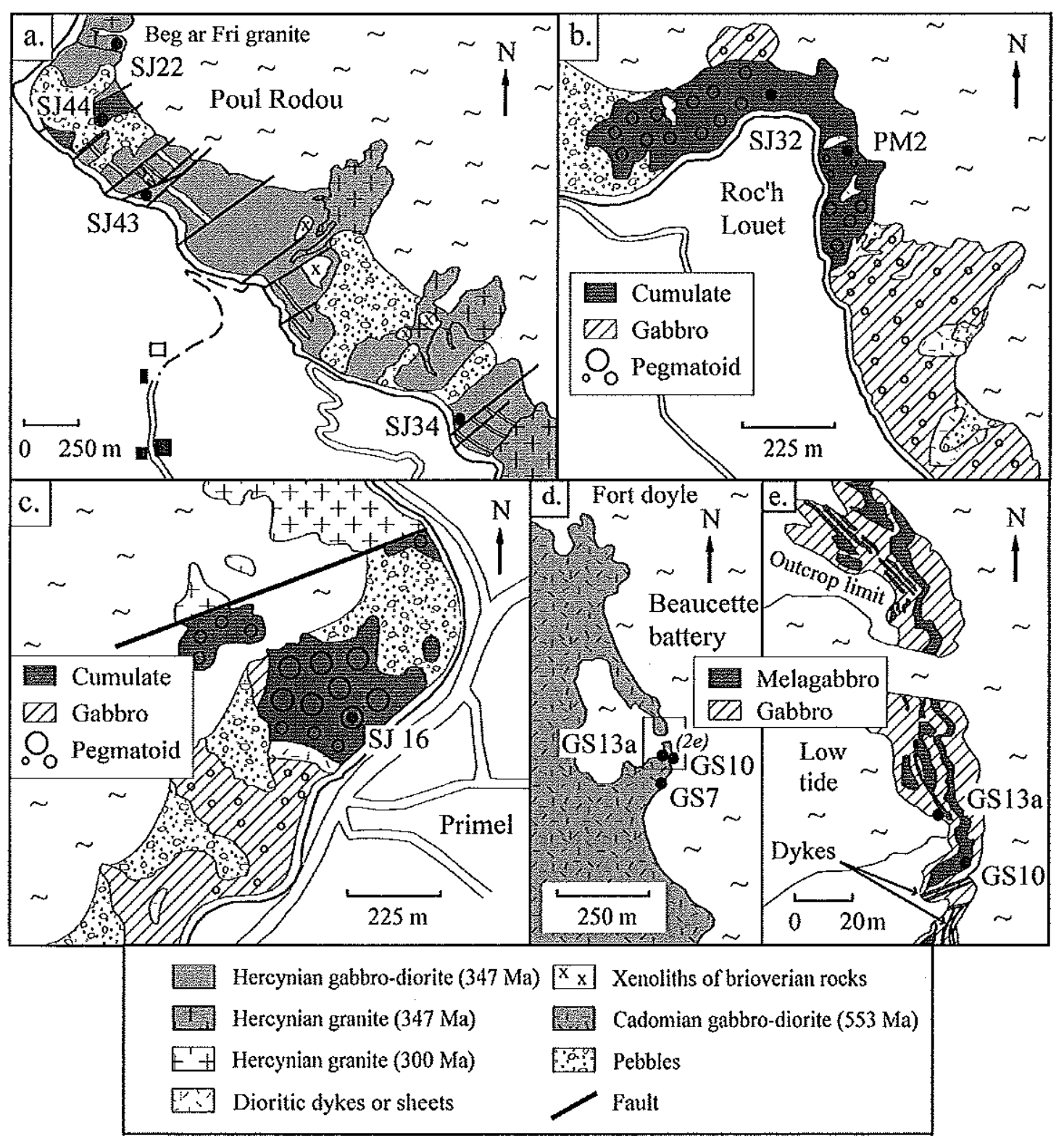

Fig. 2 

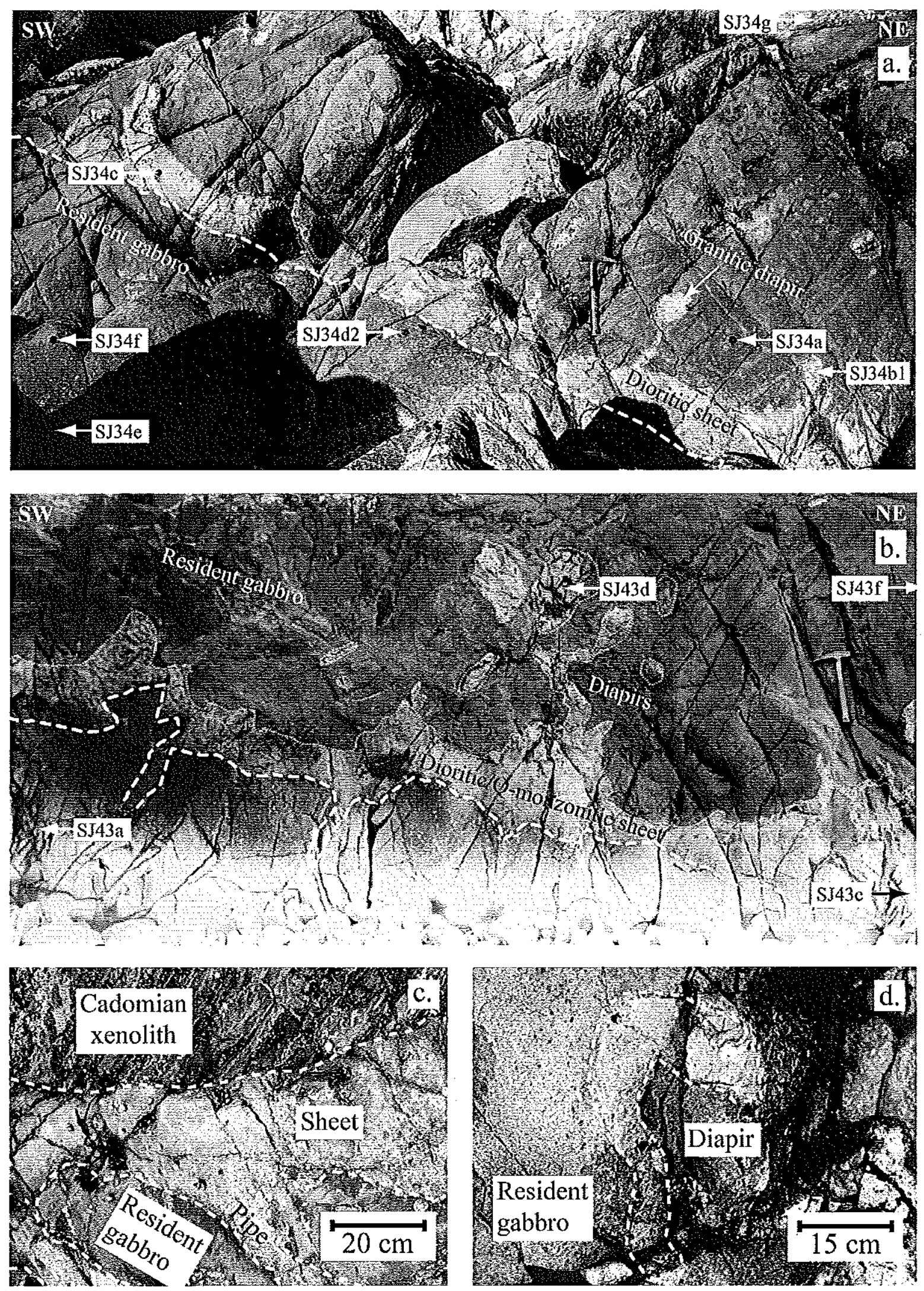

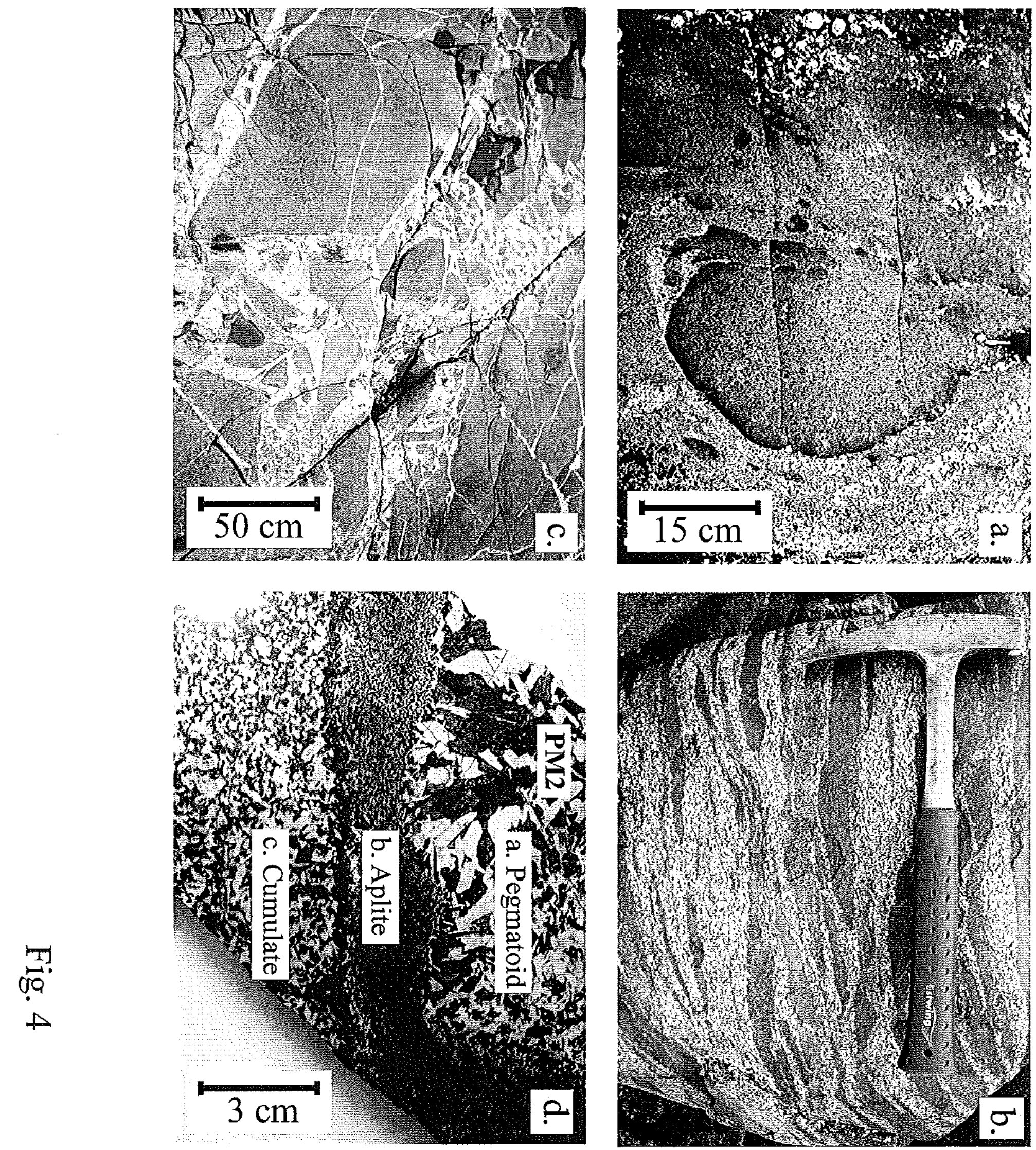

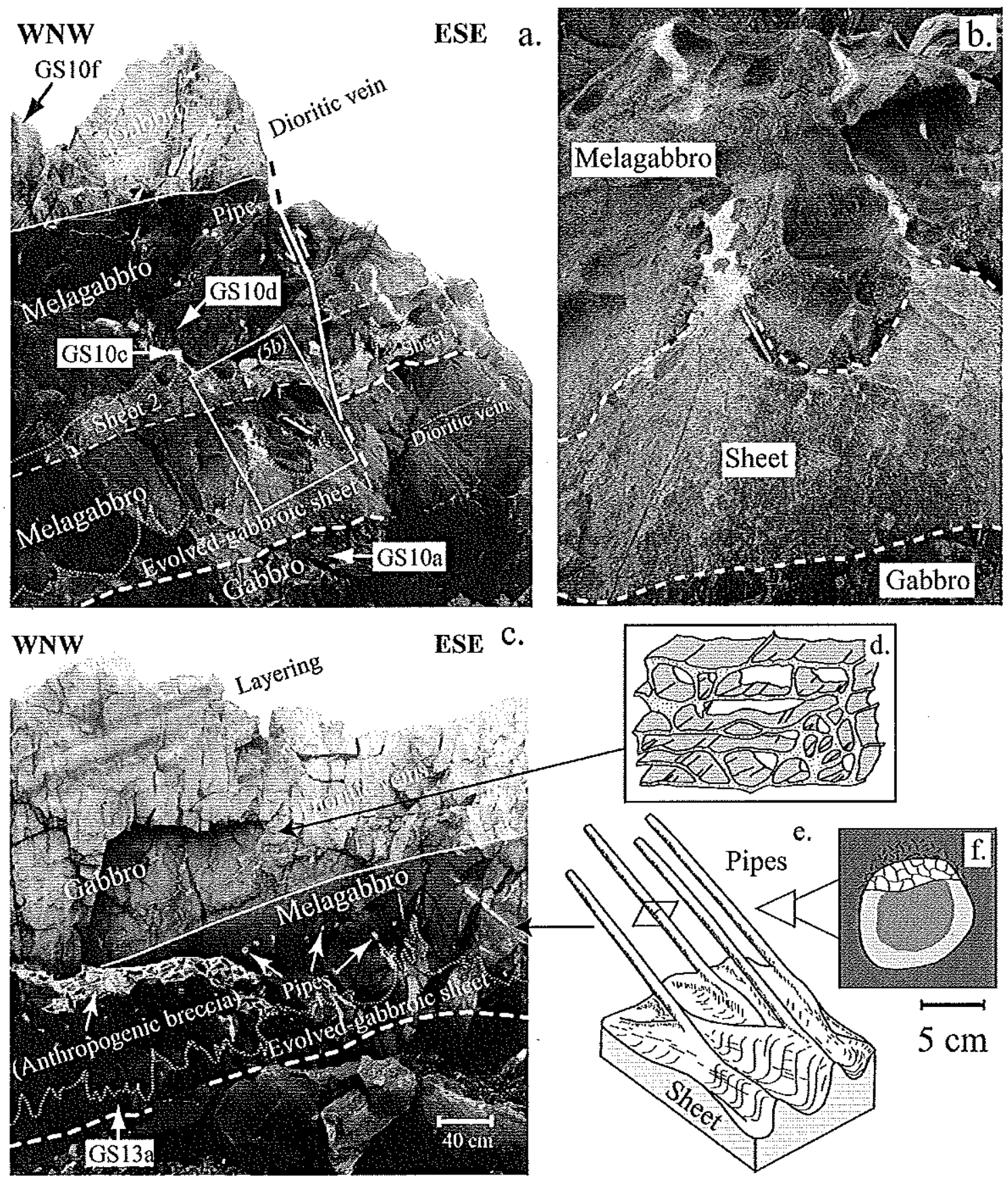

Fig. 5 

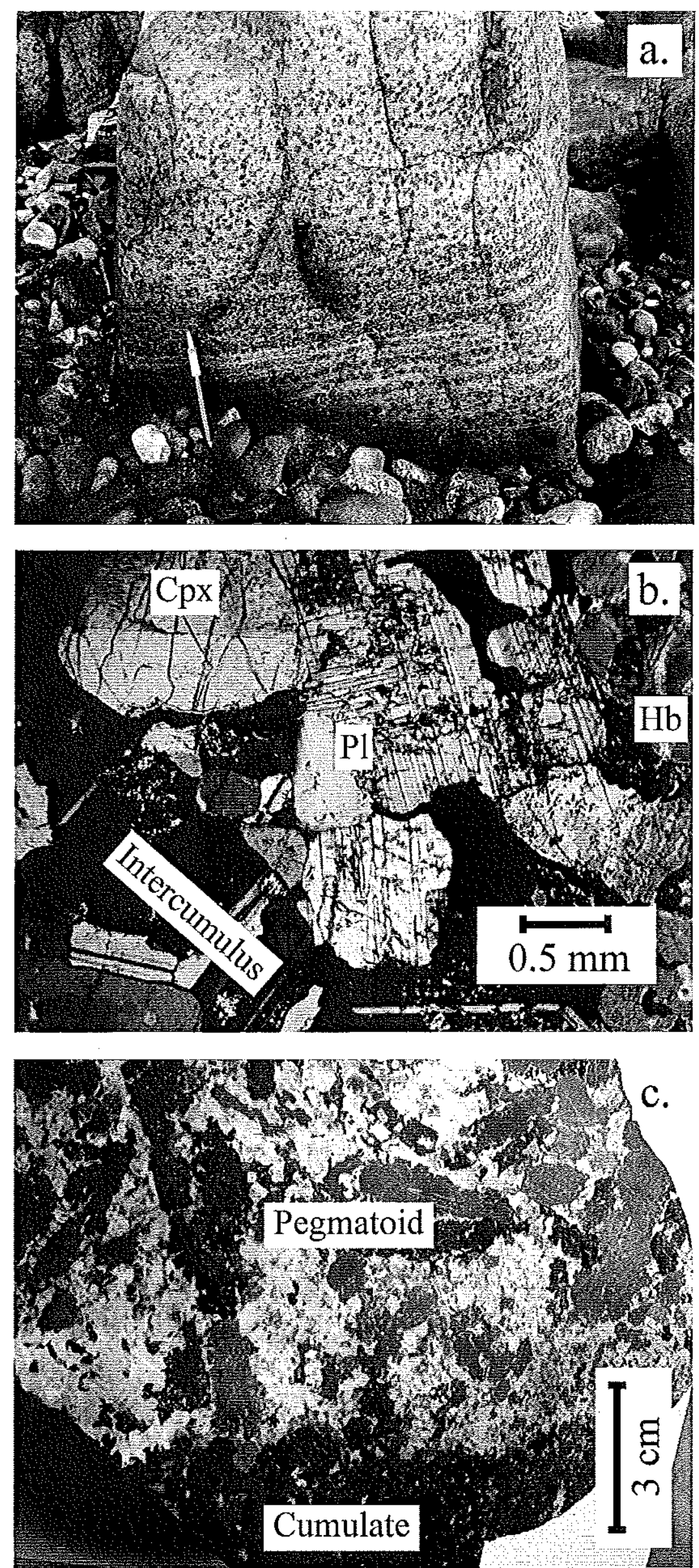

Fig. 6 

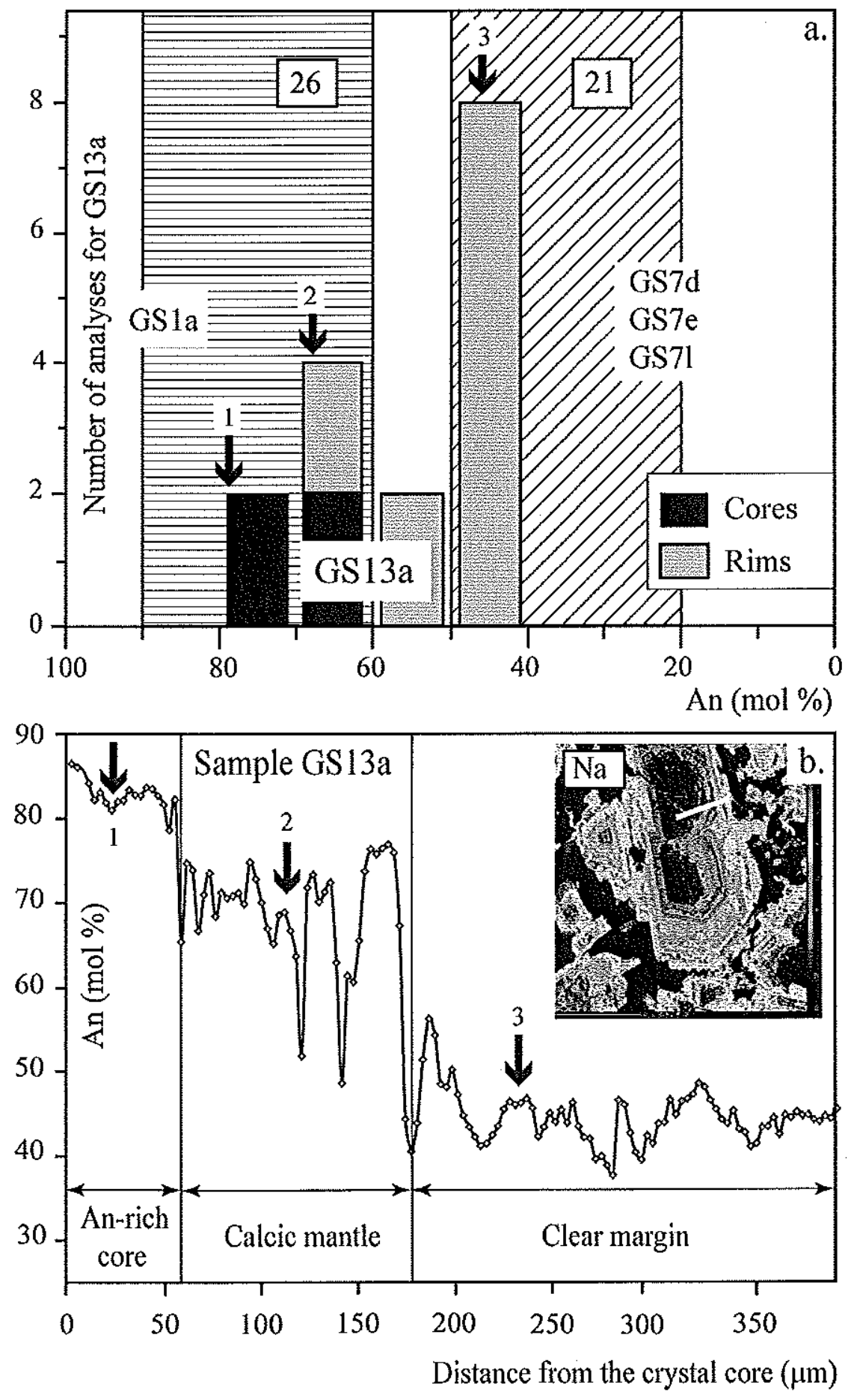

Fig. 7 


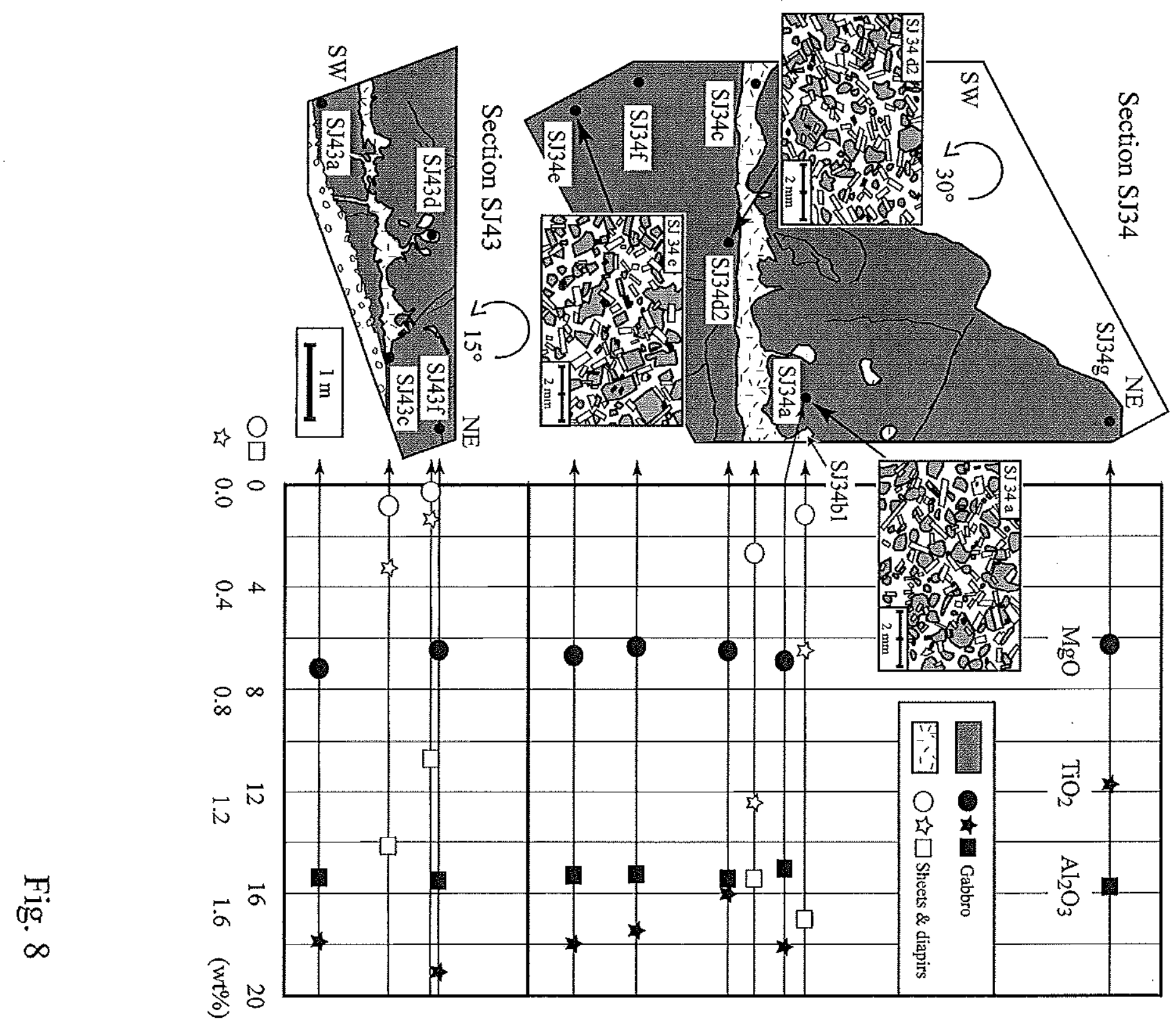




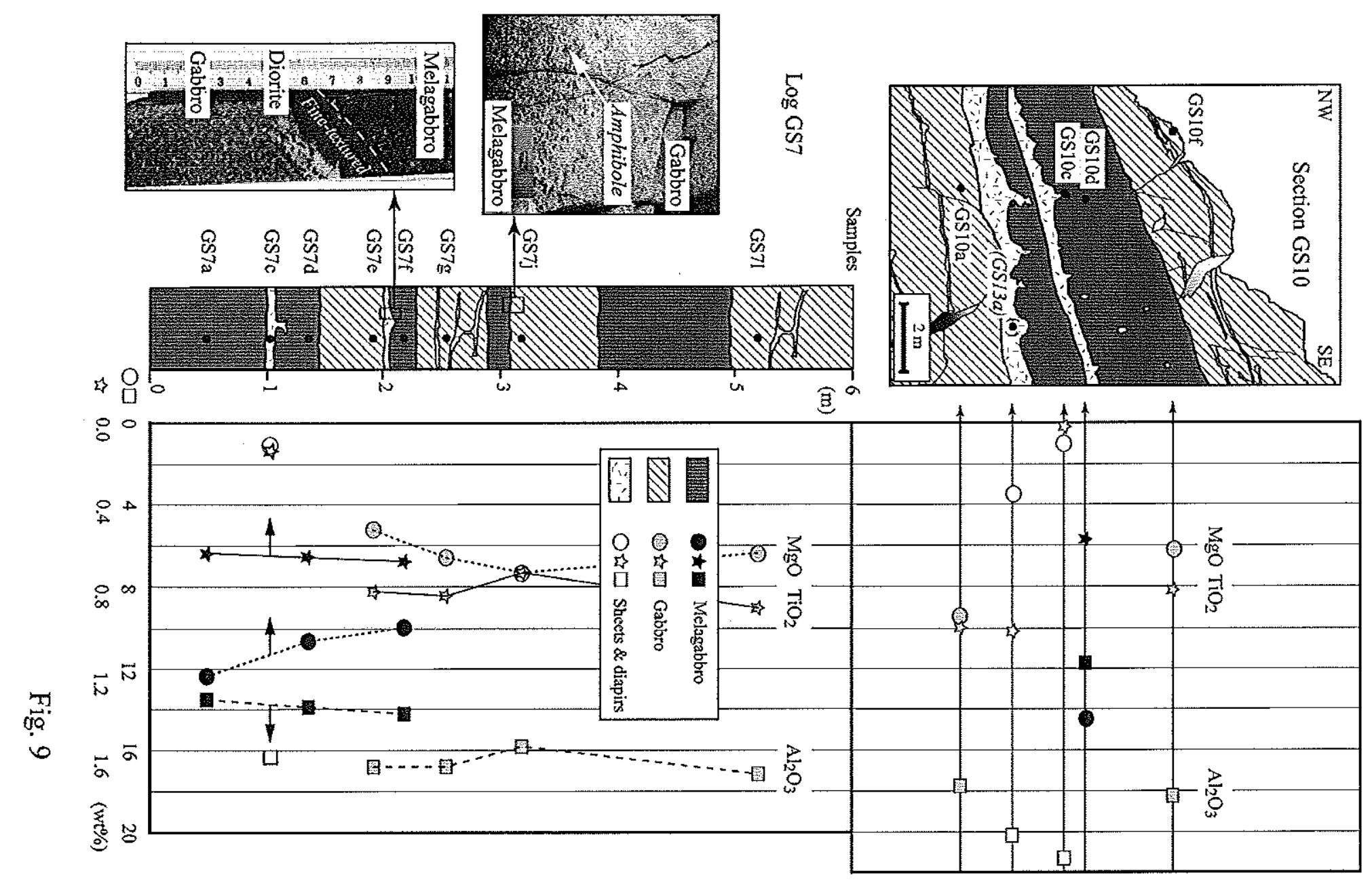




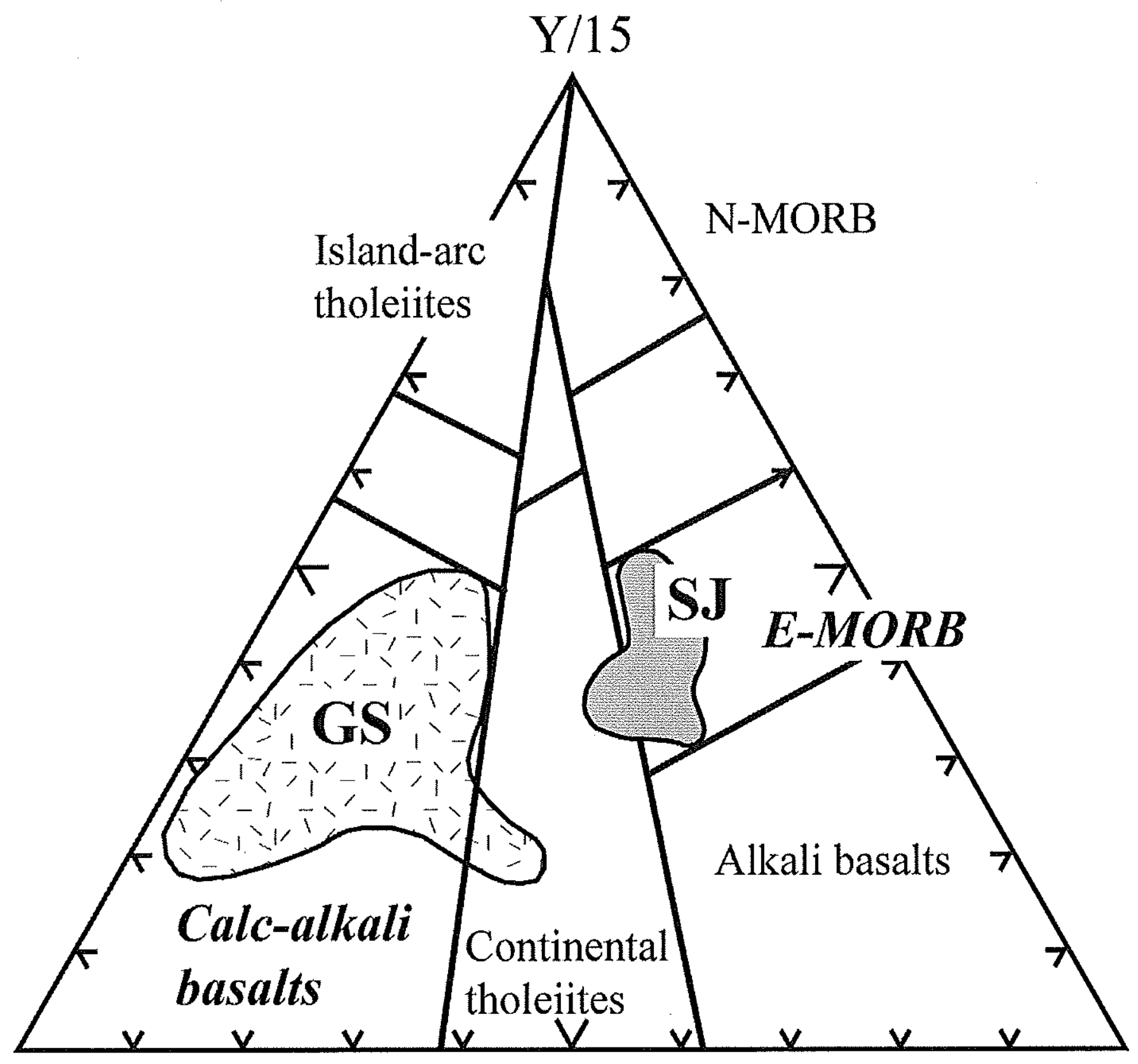

$\mathrm{La} / 10$

$\mathrm{Nb} / 8$

Fig. 10 


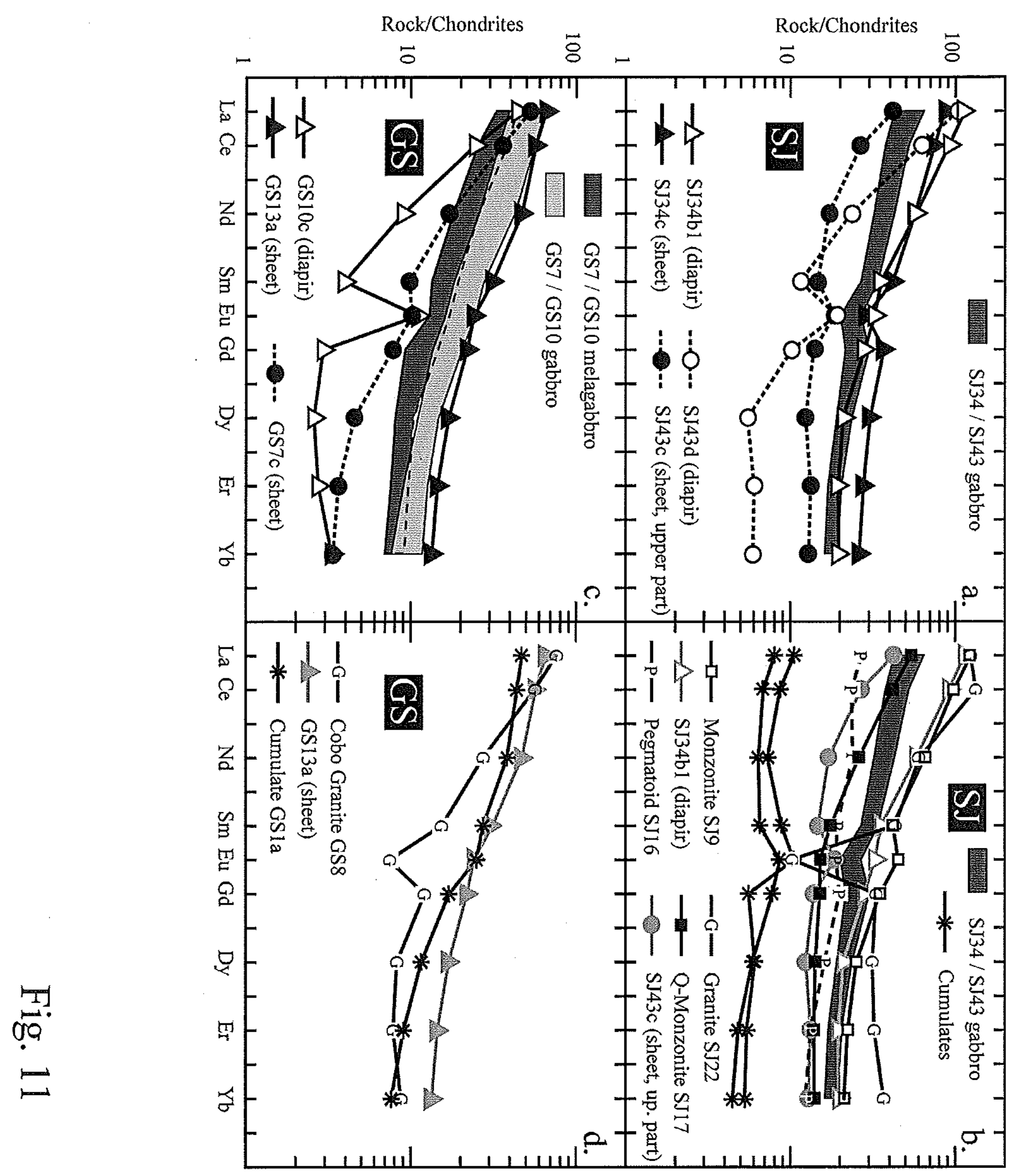



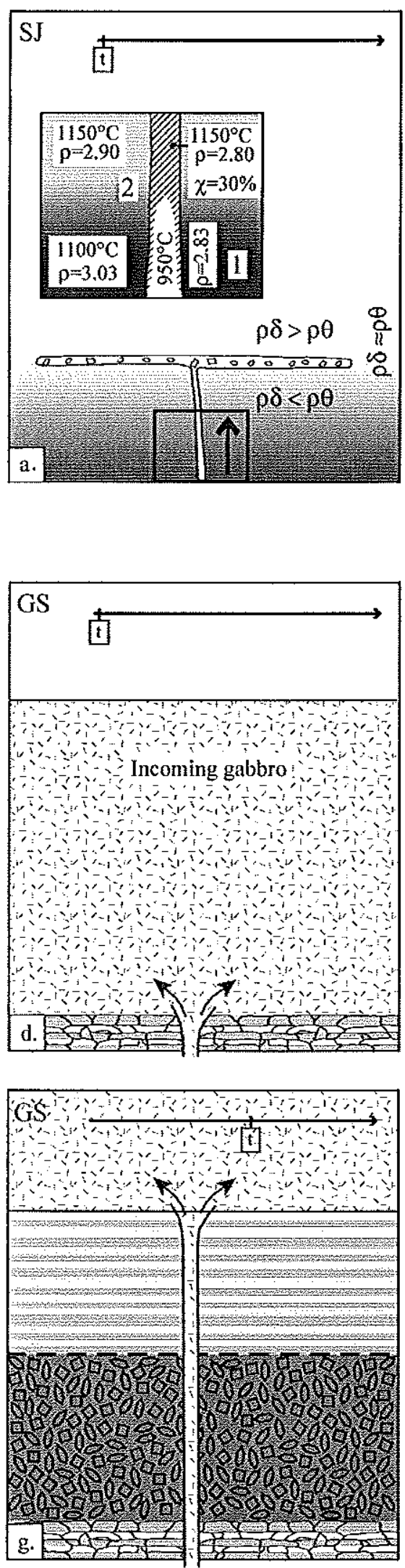
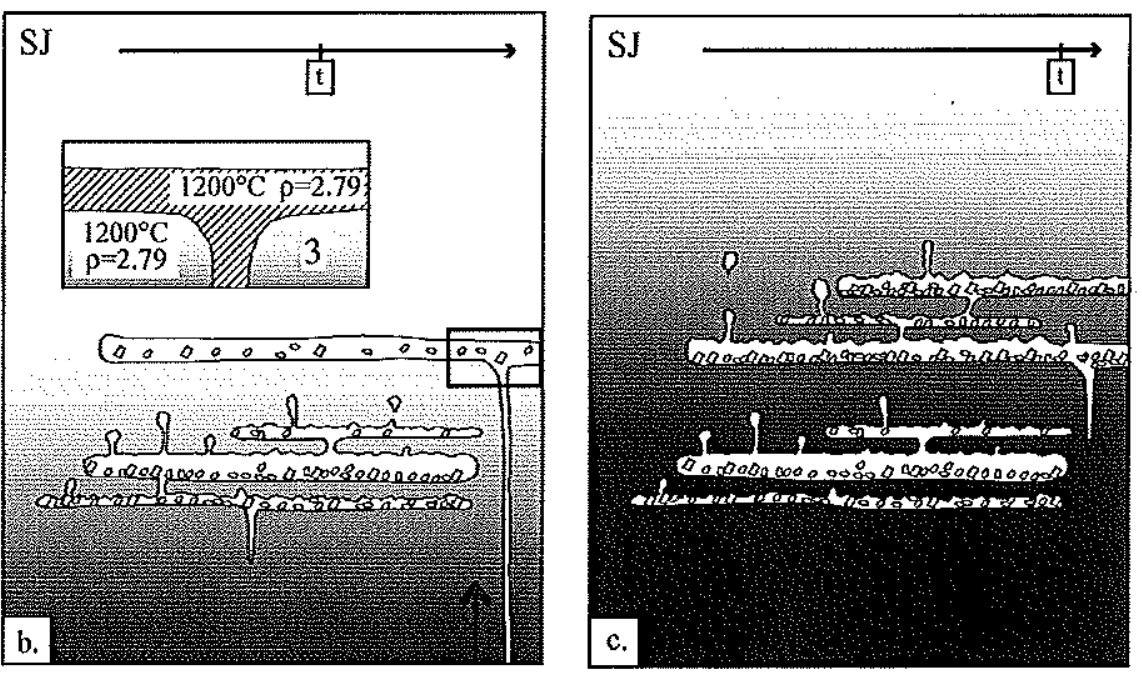

Crystallinity of the gabbro

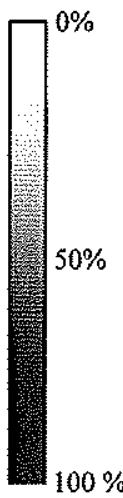

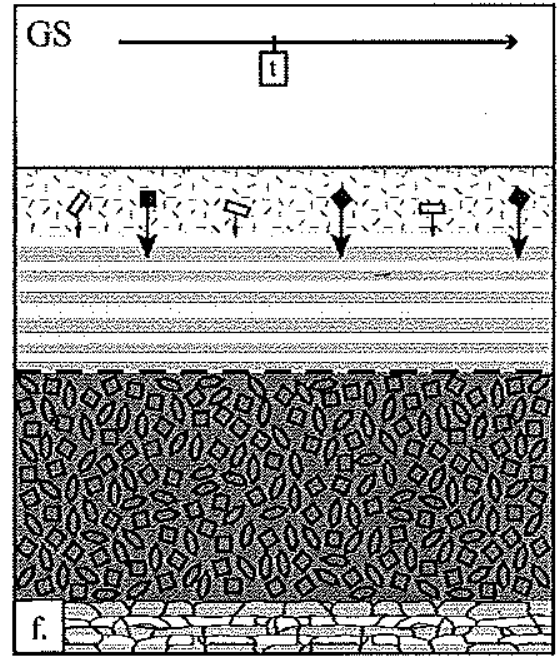
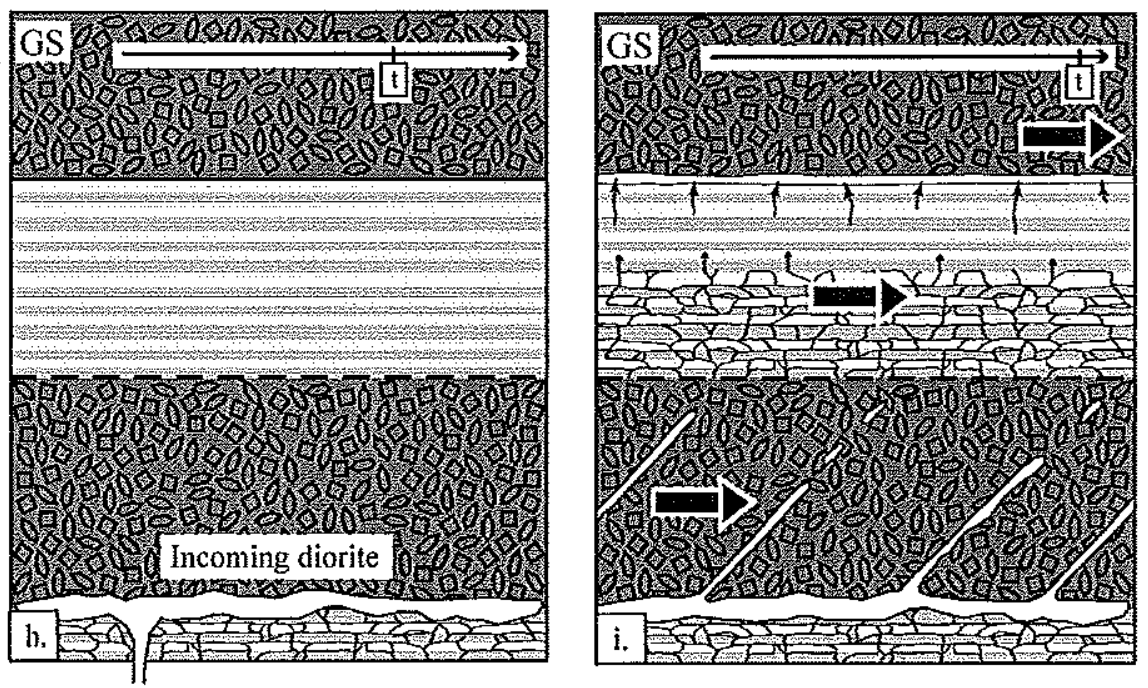

Fig. 12 


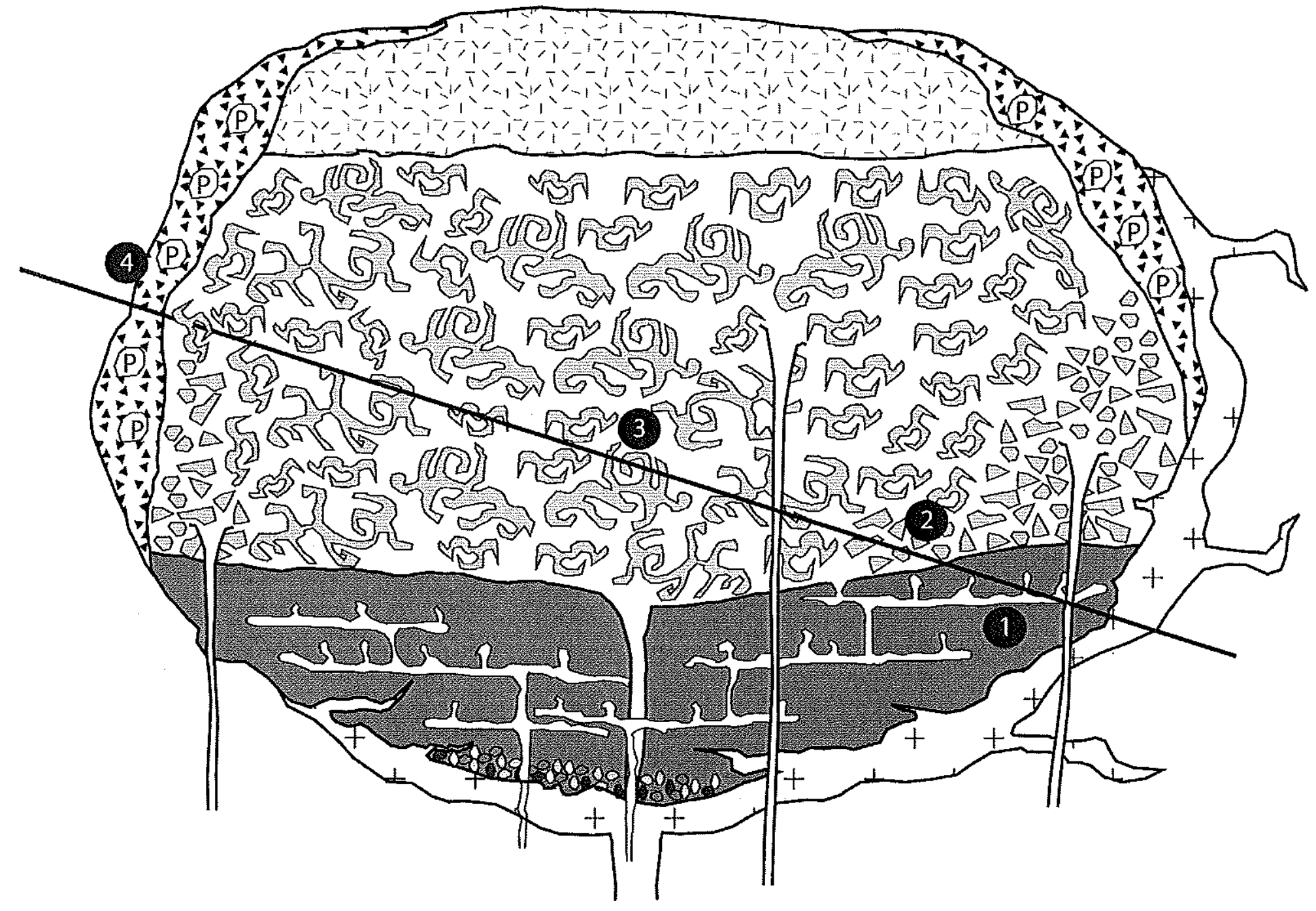

+ Granite

"

(C) Lobate facies

5 Angular breccia

Plagioclase-rich cumulate

(P) Pegmatoid
Diorite

Gabbro from Poul Rodou

Amphibole-rich cumulate

Cross-section from Poull

Rodou (1) to Primel (4)

through Saint-Jean $(2,3)$ 